\title{
Antiquity of the divyakṣetras in Pāṇḍināḍu
}

\author{
R.K.K. Rajarajan
}

Gandhigram Rural Institute - Deemed University, Tamil Nadu, India

\begin{abstract}
The Ālvārs in their hymns, the Nâlāyirativviyappirapantam, have listed 108 sacred venues or centers of worship of Viṣnu in the Indian subcontinent, called divyadeśa. The 108 are brought under certain topographical segmentations such as Malaināḍu (Kerala), Pāṇḍinaḍu (south of River Kāviri), Cōlanāḍu (Kāviri delta), Vaṭanāḍu (North India) and so on. Among these 18 are found in the Pạndya country. The hymns present a cavalcade of data bearing on these sthala/kșetras, dealing with the Mūrti, tīrtha, vrosșa, ecology, landscape, flora and fauna, $p \bar{u} j \bar{a}$ s and utsavas, mythologies bearing on Viṣnu and so on. The impact of the Vedas and Sanskritic purānas such as the Harivamiśa and Viṣnu Purāna may be found in them. Besides, the Ālvārs have recast the theme to the Tamil taste to suit the local cultural traditions. The present article presents a summary of data bearing on the 18 divyadeśas, trying to locate the roots in an ancient poem, called Paripātal. The date of the Ālvārs is briefly discussed. Among the twelve only seven have extolled the divyadeśas in Pāṇịinādu. Of the 24 integral wings of the Nālayyiram eleven talk of these sthalas. The Ālvārs have presented a picture of the deśas as they found these around the 6th-9th century CE. Later the temples under
\end{abstract}


study have developed at the hands of the successive rulers of the land down to the 18th century CE. The photographic evidences we have presented relate to such a later phase while in some cases such as Tirumeyyam the early medieval rock-cut temples and images are to be found. The text is supported by maps and photographic evidences.

Keywords: Pāṇụinādu, divyadeśa, sthala, kṣetra, Ālvār, Paripātal, Nālāyiram, Māliruñcōlai, Kōtṭiyūr, Meyyam, Pullāṇi, Taṇkāl, Mōkūr, Kūṭal/Maturai, Villiputtūr, Kurukūr, Tolaivillimañkalam, Cīvaramañkai, Pụ̣inkuți, Pērai, Vaikuntam, Varakuṇamañkai, Kụ̣antai, Kurunikuṭi, Kōlūr, sayana, sthānaka, asana.

The expanded version of the title to the present article may be "Antiquity of the Vaiṣnava Divyakșetras in Pāṇ̣ināḍu (precisely Pāṇtinātu) at the southern-most extremity of the Indian subcontinent." By immortal tradition, it is believed that the Vaisnava divyakșetras or divyadeśas are 108. ${ }^{1}$ The Tamil Vaiṣnava mystics, the Ālvārs, have extolled the praise of all these places in their hymns, called Nālāyirativviyapirapantam (shortly Nālāyiram), known as the Drāvida-veda. ${ }^{2}$ The Ālvārs were twelve in number. They are Poykai, Pūtam, Pēy, Nam (T. Cațakōpan, Skt. Șaṭagopa), Maturakavi (Skt. Madhurakavi), Kulacēkaran (Skt. Kulaśekhara), Tiruppāṇ, Tonțarațippoți, Tirumalicai, Periya (T. Viț̣ucittan̄, Skt. Viṣnusiddha), Āṇțāl and Mañkai (Kaliyan, also Ālināțan), all names suffixed with ālvār. Ālvār means one deeply immersed in love with Viṣnu, T. Māl or Tirumāl (Kalidos1976: 103). The Ālvārs were held in very high esteem by the Tamil Vaiṣnavas in sofaras they were considred to be the Lord Viṣnu himself or his various angas, deified and festivals held in their honor, especially on the day of their natal star. According to a purāṇic concept Nam and Pūtam were the tiara of Viṣnu, Poykai and Pey the Lord's eyes, Periya the face, Tirumalicai the neck, Kulacēkaran and Tiruppān the hands, Toṇtarațippoți the chest,

\footnotetext{
${ }^{1}$ A later compilation, Śrittattvanidhi (6. 335) of Krșnarāja of Mysore (19th century), lists 112 kṣetras that includes Ahobalam, Yathotkāri, Śrīmușṭ̣a (Śrīmuṣṇam), Mannnarkuți, Mahișūrsthān (Mysore) and so on (Kalidos 2006: 307, cf. Hardy 1983: 256-61).

${ }^{2}$ For an alphabetical list of these places, listed by R.K.K. Rajarajan, see Kalidos 2006: 303-308.
} 
Tirumankai the umbilicus and Maturakavi the sacred feet (Devanathan 1971: Annexure p. 85). Nātamuni codified their magnum opus, collectively called Nālāyiram, at about the 10th century AD (Aiyangar 1940: 260, Hardy 1983). This work consists of 24 pieces. They are:

\begin{tabular}{|c|c|}
\hline Author & Name of the work \\
\hline Poykai & Tiruvantāti I \\
\hline Pūtam & Tiruvantāti II \\
\hline Pēy & Tiruvantāti III \\
\hline \multirow[t]{4}{*}{ Nam } & 1. Tiruvāciriyam \\
\hline & 2. Tiruviruttam \\
\hline & 3. Periya Tiruvantāti \\
\hline & 4.Tiruvāymoli \\
\hline Maturakavi & Kaṇṇinuṇciruttāmpu \\
\hline Kulacēkaran & Perumāl Tirumoli $i$ \\
\hline Tiruppāṇ & Amalanātipirāan \\
\hline \multirow[t]{2}{*}{ Toṇțarațippoṭi } & 1. Tirumālai \\
\hline & 2. Nāñmukan Tiruvantāti \\
\hline \multirow[t]{2}{*}{ Periya } & 1. Tirumoli \\
\hline & 2. Tiruppallāṇtu \\
\hline \multirow[t]{2}{*}{ Āṇtạạ } & 1 Tirupāvai \\
\hline & 2. Nācciyār Tirumoli $i$ \\
\hline \multirow[t]{6}{*}{ Tirumañkai } & 1. Periya Tirumoli \\
\hline & 2. Tirukkuruntāṇtakam \\
\hline & 3. Tirunețuntāṇtakam \\
\hline & 4. Tiruvelukūrrirukkai \\
\hline & 5. Ciriyatirumatal \\
\hline & 6. Periyatirumațal (cf. Kalidos 1999a: 223-24n). \\
\hline
\end{tabular}

The date of the Ālvārs is not so vexed a question. Kamil V. Zvelebil (1974: 101-104) dates Poykai, Pūtam and Pēy at CE 650-700 and Āṇtạal, including Tonțarațippoți, in the 9th century (cf. Hardy 1983). Kalidos dates Poykai to Pēy in the 5th-6th century, Nam to Tirumalicai in the 7th-8th century and Periya to Mankai in the 8th9th century. Poykai to Pēy, known as Mutal Ālvārs "Early Ālvārs", are more likely to be dated in the 5th-6th century on a logical sequence of the Tamil bhakti literature for which the Vaișnavas and their counterparts, the Śaivas have contributed. Some of the Śaiva mystics, e.g. Kāraikkālammaiyār, are dated in the 5th century CE. An important question to be posed here is: who inaugurated the saga of composition of the bhakti literature in Tamil? Whether did the 
Vaiṣnavas or Śaivas? If the Mutal Ālvārs are to be dated in the later half of the 7th century $\mathrm{CE}$ as suggested by Zvelebil, it is understood that the Śaivas began the Tamil bhakti earlier since Kāraikkālammaiyār is dated in the 5th-6th century CE (Zvelebil 1974: 91 dates her in CE 500). The rudiments of Vaiṣnava bhakti may be found in the Paripattal, a post-Cankam work, assigned to the 4th century CE by Zvelebil. Its continuation occurs in the Aycciyarkuravai of Cilappatikäram, dated in the 5th century CE by Zvelebil (for a comprehensive analysis of these poems see Hardy 1983), which most art historians, including Raju Kalidos accept. The Mutal Ālvārs took up further work only in the later half of the 7th century if Zvelebil's date is considered. Thereby, there arises a hiatus in Vaișnava bhakti during CE 550-650. Logically, in a historical sequence it could not be so. It is a known fact that bhakti is the outcome of the Bhāgavata movement in the North that may be fixed in the early centuries of the Christian era (cf. Bhandarkar (1913/1995). It is likely to have percolated to the South and had its impact on composers of the Paripātal and Ilanikōvațikal, author of Cilappatikāram, in the 4th-5th century. ${ }^{3}$ The Mutal Ālvārs must have continued the tradition in the later 5 th or early 6 th century $\mathrm{CE}$ so that from the Paripātal to Mutal Ālvārs, there is an unbroken Vaiṣnava bhakti activity. The Nāyanmār enters the scene around the 5th

\footnotetext{
${ }^{3}$ Brockington (1981/1991) advocates a controversially debatable thesis that the origin of Tamil bhakti is in the Tirukkural (Brockington's 1991: 130-31 date 4th century $\mathrm{AD}$ ), which is a didactic work that could also be a blend of dharma-, artha- and $k \bar{a} m a$-śästras. The author of the work, Valluvar, has no pretext to talk about God, excepting in the invoctory part that invites the presence of the Muse, which talks of God in generic terms and mentions no name of a personal God such as Viṣnu or Siva. Interpretations may bring Siva, Viṣnu or Brahmā into the piture but these are vague. For example, Malarmicai ékin̄an (Tirukkural v. 3) "one who is mounted on a flower", i.e., Brahmā (cf. Malaravan or Malarn̄ōn, Tèvaram 3.276.9, 1.7.9), Tanakkuvamai illātān (Tirukkural v. 7) "the Lord to whom none is a match" maybe either Śiva or Viṣnu (cf. Muñikāṇmūrtti "Seer seen by the seers", Tēvarkulakkoluntu "Sprout of the House of Gods", Tēeāram 7.4.3, 1.50.4), Aravāliantanan (Tirukkural v. 8) "the righteous person (brāhmaṇa)", i.e. Brahmā. Tirukkural v. 10 notes God with the generic term iraivan. The author vaguely notes Brahmā that might suggest he is a brāhmana. If one advocates such a fascinating theory, a fanatic Tamil scholar may declare a jehad because the author, Valluvar (soothsayers' caste), belonged to a pañcama family (Hanumanthan 1996-97: 51). Jain scholars consider Tirukkural a piece of heterodoxical work (Bhaskaran 2001: 33). Again, the intense devotionalism that melts the tissues of a devotee as in the Tèvāram or Nālāyiram (cf. Kalidos 1996: 78-89) is totally missing in the Kural.
} 
century. At this place, it may be noted that there is no exclusive literature on Śiva or Śiva-bhakti down to the 5th or early 6th century. The Cankam and post-Cañkam literature has an exhaustive work on Murukan, the Tirumurukārrappatai, including Paripātal, and Devī in the Vettuvavari section of Cilappatikāram. Where is the place of Śiva in these works? He is not even considered to be the god of a particular tinai (e.g. kuriñ ci, cf. Jeyapriya 2004). Siva's personality is projected only after the time of Kārakkālammaiyār, particularly in the hymns of the Têväram-trio (cf. Kalidos 1996: 13-56).

The antiquity of Māliruñcōlai could be pushed a few centuries back as it figures prominently in the Paripātal (vv. 1-4, 13, 15, Paripātal-tirattu v. 1). The first verse invokes the Lord in the nāmāvali pattern as follows:

Thou are dharma,

Thou are Blessing,

Thou are Righteousness,

Thou are trouble to trouble-mongers,

Thou are the Sun, Moon and Fire,

Thou are Śiva and his action, i.e. samhāra,

Thou are the Veda,

Thou are Brahmā and his action, i.e. srșți,

Thou are the pañcabhütas and

Thou are the Himālayas. (Paripātal v. 1 II. 37-48)

The Lord's Viśvarūpa is visualized in v. 3 II. 1-10, saying his hands are two to ten, $1000,10,000$ or 1,00,000. Māl's archaic name is Māayōy (Paripātal 2 I. 1). The Viśvarūpa visualization is again repeated in vv. 4 II. 70-73, 13 II. 16-22. A clear impact of the Bhagavatgit $\bar{a}$ could be discerned as it is said:

Thou are Cold in Fire,

Thou are Fragrance in Flowers,

Thou are a Gem among stones,

Thou are Truth in words,

Thou are Love in dharma,

Thou are the Child of Heroism,

Thou are the Veda of the Vedas,

Thou are the First (i.e., land) among bhütas,

Thou are the Light of Sūrya (sun),

Thou are Frigidity in Candra (moon), 
Thou are All,

Thou are the inner Meaning of All.

(Paripātal v. 3 II. 63-68, cf. Bhagavadgītāa, Adhyāya 10, vv. 21-38) ${ }^{4}$

Māliruñcōlai is called Nețun̉kuñram, Iruñkuñram and Mālirunikuñram (Paripạtal 15. 11. 4, 14, 17, 23). Interestingly, Vēnkațam fails to appear. On the other hand, two other kșetras, Iruntaiyūr and Kulantai are notified in Paripạtal-tirațtu v. 1. II. 5, 63). Even if Vēnkațam fails to appear in a Pāndya country literature as is the Paripātal, it appears in earlier Cankam works, e.g. the Akañ̄nūru (e.g. vv. 27, 61) and Puranānūru (v. 391). Therefore, its antiquity could be taken back to the early centuries of the Christian era, one or two earlier in the BCEs. Therefore, Vēnkațam happens to be the earliest Vaiṣnava divyakșetra, predating Arañkam and Māliruñcōlai. It may note that even if traditional scholars bring Vēnkatam under North India and that it today falls in Andhra Pradesh, in those time of Paripātal it was within the decent limits of Tamilkūrumnallulakam "the good land where pristine Tamil is spoken" (Kalidos 1999: 146), i.e. Tamilnadu. Kulantai is the same as it happens to be one among the 18 in the Pāṇdya country. Even if it occurs only in the hymns of Nammālvār, its antiquity could be sent to the 4th century AD. Iruntaiyūr's identification is a problem. It appears in an earlier Cankam literature, the Kuruntokai v. 335, assigned to c. 200 BCE to CE 200. Some consider it Māliruñcōlai because the Lord is irunta "seated" (and so Iruntaiyūr) in this kșetra. It could not be taken for granted because Viṣnu is seated in four places of the Pāṇdyan sphere.

$\bar{A} n \underline{n} \operatorname{ạ} l$ in her work has a reference to the rise of Venus (Śukra, T. Vellii) and fall of Jupiter (Brhaspati or Guru, T. Viyālan ); velliyeluntu viyalamurañkirru, Tiruppāvai v. 13. Astronomical calculation says, it falls in CE 731 (cited in Kalidos 1976: 104). Therefore, Ānțāl may be dated in the 8th century. Periyālvār being her foster-father belongs to the same century. Periyālvār in his hymns notes the Pāṇdyan Emperor, Nețumāran (PTM 4.2.7), identified with Jațila Parāntaka Nețuñcațaiyan alias Varaguna I, dated in CE 765-815 (Sastri 1929/1972) or 765-783 (Pandarathar 1974). The scheme adopted by Pandarathar would keep Periyālvar within the limits of the 8th

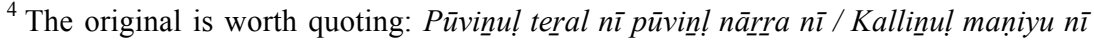

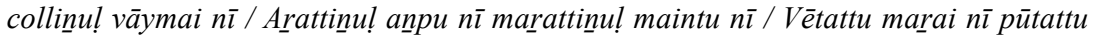

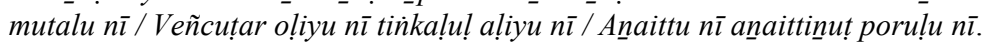


century. Periyālvār was ripe old who out-lived Ānțāl . She passed on to the Vaikunțha (the Vaiṣnava heaven) willingly at a young age. Her foster-father would not have survived long after the demise of his beloved daughter. Mankai received the favours of the Pallava Emperor Nandivarman II (CE 731-96). Mankkai must have been young at the time of his association with the Pallava Emperor and lived down to the early 9th century CE. In any case, all the $12 \bar{A}$ lvārs could conveniently be placed within the time scale of later 5th or early 6th to early 9th century CE. Their literary dramatics lasted for nearly 300 years.

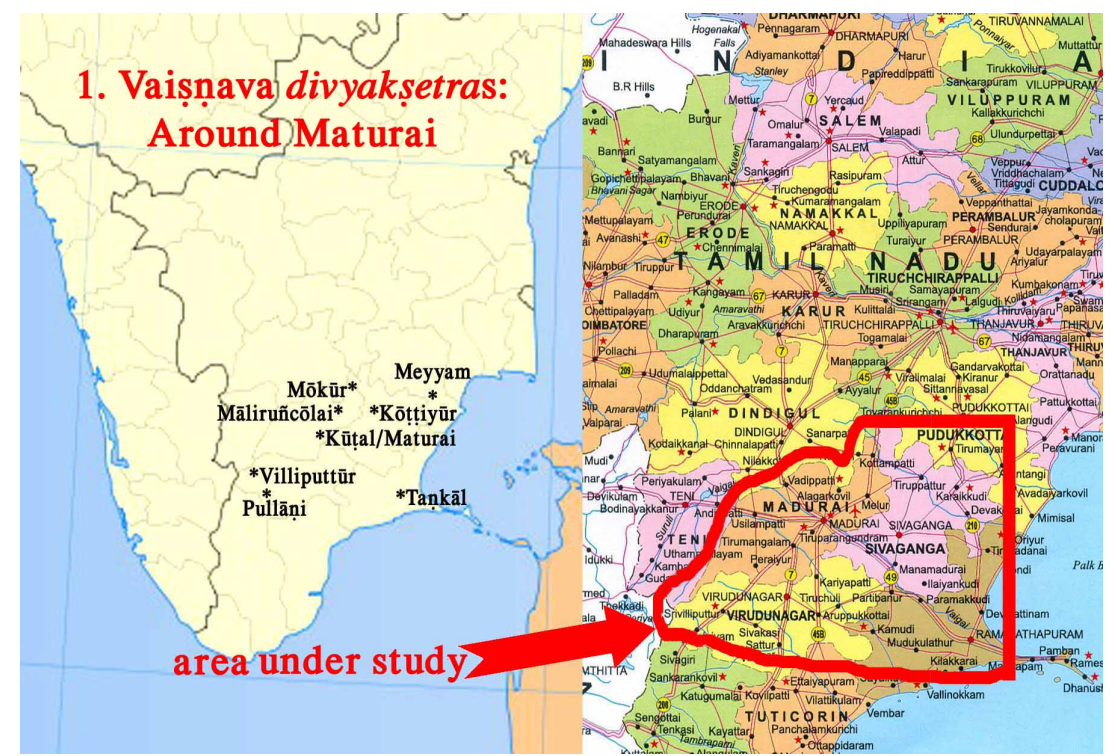

Map 0.1: Vaișnava divyakṣetras: Around Maturai.

Regarding the key-theme of investigation, it may state at the outset that Pandininādu is the land that falls to the south of the River Kāviri (see map 1). The Konku (western Tamilnadu) and Putukkōttại (northeast along with coast of the Bay) altered their allegiance to either the Pāndyas or Pallavas, depending on the fortunes of these powers in the concerned zones. Most of the divyaksetras in Pāndinādu, 18 in total, fall to the south of Māliruñcōlai (now called Alakarkōyil in suburban Maturai). Meyyam is midway between Putukkōtțai and (Tirup)Pattūr (cluster of ten villages? or Puttūr hamlet 
of anthills?) on the Maturai highway. The other centers are Kōtṭiyūr (Skt. Koștịūr), (Tirup)Pullāṇi (splinter like nail?), (Tirut)Taṇkāl, (Tiru)Mōkūr, Kūțal (Maturai), Villiputtūr, Kurukūr, Tolaivillimañkalam (now called Tollaivillimañkalam), ${ }^{5}$ Cìvaramañkai, Teñtiruppēreyil, Vaikuntam (Skt. Śrīvaikuṇtham), (Tirup)Puḷinkuṭi, Varakuṇamañkai, (Tiruk)Kulantai, (Tiruk)Kuruñkuṭi and (Tiruk)Kōḷūr. Kūṭal, Mōkūr and Māliruñcōlai are within the limits of Greater Maturai. Kōtțiyūr and Tiruppullāṇi are to the east, centering on Rāmanātapuram. Taṇkāl and Villiputtūr are on the way from Maturai to (Tiru)Nelvēli. All other places hover around Nelvēli. The popularization of the kșétras around Nelvēli was mainly due to the inspiration of Nammālvār who had his base at Kurukūr (now Ālvārtirunakari), his place of birth.

At this place, it is pertinent to note that the 108 divyaksetras are scattered over the topographical segments of Tamilnadu, Āndhradeśa, North India and the Heavens. Within Tamilnadu and outside the distribution pattern is:

\begin{tabular}{|c|c|}
\hline Pāṇḍināḍu & 18 \\
\hline Cōlanāḍu & 40 (e.g. Tañcāvūr) \\
\hline Malaināḍu (Kerala) & 13 (e.g. Anantapuram) \\
\hline Toṇtaināḍu & 25 (e.g. Kāñcīpuram, including Vēṅkațam) \\
\hline $\begin{array}{l}\text { Vațanāḍu (including } \\
\text { Āndhradeśa) }\end{array}$ & 9 (e.g. Dvārakā, Mathurā) \\
\hline Mythical & 3 (e.g. Pārkațal, Skt. Kșīrāābdhi) \\
\hline
\end{tabular}

The above statistics would prove the Vaișnava bhakti was intensive in the Cōlanādu and Tonțaināḍu regions, Pạṇ̣ināḍu coming third in the order of numerical priority of the ksetras. Of all the kșetras in the Cōlanādu region, three are early. They are Arañkam, Kuṭantai (Kuṃbhakoṇam) and Viṇnakaram (Oppiliyappankōyil). Ten are early in the Toṇtaināḍu region. They are Kōvalūr, Kacci (Kāñcīpuram), Vēlukkai (Kāñci), Pāṭakam (Kāñci), Veḥka, Nīrmalai, Kaṭnn̄mallai, Allikkēni and Katikai (Cọlinkar). Three figure in the early list of North India and the mythical list. They are Vènkațam (strictly speaking falls within the bounds of ancient Tamilakam, supra),

${ }^{5}$ This is the traditional sequence of the places. It could better be Meyyam, Pullāni, Kōtṭ̣iyūr, Mōkūr, Māliruñcōlai, Kūṭal, Villiputtūr, Taṇkāl, Kuḷantai, Puḷinkuṭi, Varakuṇamañkai, Vaikuntam, Tolaivillimañkalam, Kurukūr, Tiruppērai, Kōlūr, Cīvaramaṅkai and Kurunkuṭi. 
Pārkațal and Paramapatam (Vaikunțha). Out of the 108, 22 are early kșetras, extolled by the Mutal Ālvārs. Excluding two of the mythical list, taking Vènkațam into account 20 places are historically important as centers of Vaiṣnava bhakti that could be dated to the later 5th and early 6th century AD. Among these Māliruñcōlai, Arañkam and Vènkațam are very important as graphic descriptions of the kșetras appear in the Cilappatikäram (5th century AD).

Of the twelve Ālvārs, seven have extolled the kșetras in the Pāṇ̣ināḍu region. Those who have missed the kṣetras are Pūtam, Maturakavi, Kulacēkaran, Tiruppān and Tontarațippoți. Of the 24 integral wings/poems of the Nâlayyiram, 13 do not note the kșetras in Pāṇ̣̣inādu. They are Tiruvantāti III, Kaṇninūnciriruttāmpu, Perumāl Tirumoli, Amalanātipirāan, Tirumālai, Tiruvāciriyam, Tiruviruttam,

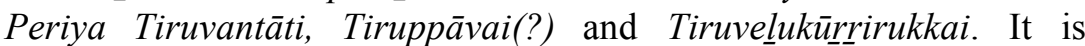
interesting to note that Periyālvār is supposed to have composed the Tiruppallielucci (Sacred Arousal [of the Lord from Slumber]) in the Kūtal Alakar temple at Maturai but there is no literary or epigraphical support for this notion. The concerned text also fails to say anything about it, excepting a vague clue to Maturai. Again, Periyālvār and Āntāạ are supposed to be residents of Villiputtūr, Periyālvār being its high-priest. Among the few hundreds of hymns composed by both these mystics, two have a bearing on the kșetra (infra) at Villiputtūr.

The ksetra in the Pantịinădu zone that could be dated to the 7th century is Kurunikuți. Mōkūr, Villiputtūr, Kurukūr, Tolaivillimañkalam, Tentiruppērai, Vaikuntam, Puḷinkuṭi, Varakunamañkai, Kulantai and Kōlur could be dated in the 8th century. Meyyam, Pullāni and Kūṭal appear in the hymns of Mañkai that could be dated in the 8th-9th century. It may note that Meyyam and Tankāl are centers of early medieval rock-cut temples. The rockcut cave for Śeșaśāyī-Viṣnu at Meyyam has been assigned to a much early date, may be the 6th century CE on art historical considerations (Rajarajan 2006: 59-61, Latha 2005: 29-32). Fact must have been that Meyyam did not receive popular appreciation until the time of Mankai who was the first to versify the place and thereby added value to its cult. The structural additions to the original cave temple could be dated since the early Pandiya period in the later half of the 9th century, particularly during the later Pāndys down to the Vijayanagara-Nāyaka period as attested by the epigraphical sources (vide, Rajarajan 2006, 
Latha 2005) and literary clues. Therefore, the temple that received the attention of Mankai was the original rock-cut cave, including few structural additions. Tankāl figures in the hymns of Pūtam and Mankai. That is to say, the cave temple on the site must have been existing by about the early 6th century. Of late scholars (Rajarajan 1991, 2006; Latha 2005), question the theory that Mantakappatțu was the earliest cave temple in Tamilnadu. Basing on the Pillaiyārpațti inscription in the rock-cut cave therein, dated at the end of the 5th century CE (cf. Mani 1990: 37-38), it is argued the cave temple tradition in the Pāṇdināḍu region begins somewhere at the end of the 5th century CE, following the Guptas at Udayagiri in Central India. Therefore, even if Meyyam appears in a later literary work, its earlier origin could not be disputed.

Māliruñcōlai appears in the hymns of Pūtam, Nam, Periya, $\bar{A} n \underline{n} \bar{l} l$ and Mankai. The mūlabera in the temple is sthanaka. The vimāna is of special importance because from the base, upapitha, to the grivva the geometrical shape is circular. Kōttiyun appears in the hymns of Pūtam, Pēy, Malicai, Periya and Mañkai. The mūlabera is in bhujangasayana mode. Meyyam (supra) and Pullāni appear in the hymns of Mankai. The mülabera at Meyyam is sthānaka as it appears in the later structural temple. The original dedication was to sayanamūrti (Kalidos 2006: Pl. III). ${ }^{6}$ The mülabera at Pullāni is in àsana mode. The later structural temple at Taṇkāl houses a sthānaka image while the original dedication was to sayanamurti in the small cave temple therein (Kalidos 2006: Pl. 5.2). The Mōkūr temple houses a sthānaka image but its original dedication was to sayanamūrti that appears in a subsidiary chapel. The ground floor of the Kūtal Alakar temple houses a āsana-Mūrti. The vimāna here is aștāinga and houses all-three forms, the sthānaka and sayana appearing the upper storeys. Villiputtūr appears in the hymns of Periyālvār and Ānțāl. The mülabera is believed to be vatapatrasayana, the Lord who reclines on the leaf of vata (T. āl, Ficus bengalensis). The temples at Kurukūr, Tolaivillimañkalam, Cīvaramañkai, Tentiruppēreyil, Vaikuntam, Puḷinkuṭi, Varakuṇamañkai, Kulantai and Kōlūr appear in the hymns of Nam (see map 2).

\footnotetext{
${ }^{6} \mathrm{We}$ will take up this problem for discussion later. The question is why the original dedication should alter in a later age. We want to take the literary clues in the Nālāyiram and the type of Mūrtis that appear today.
} 


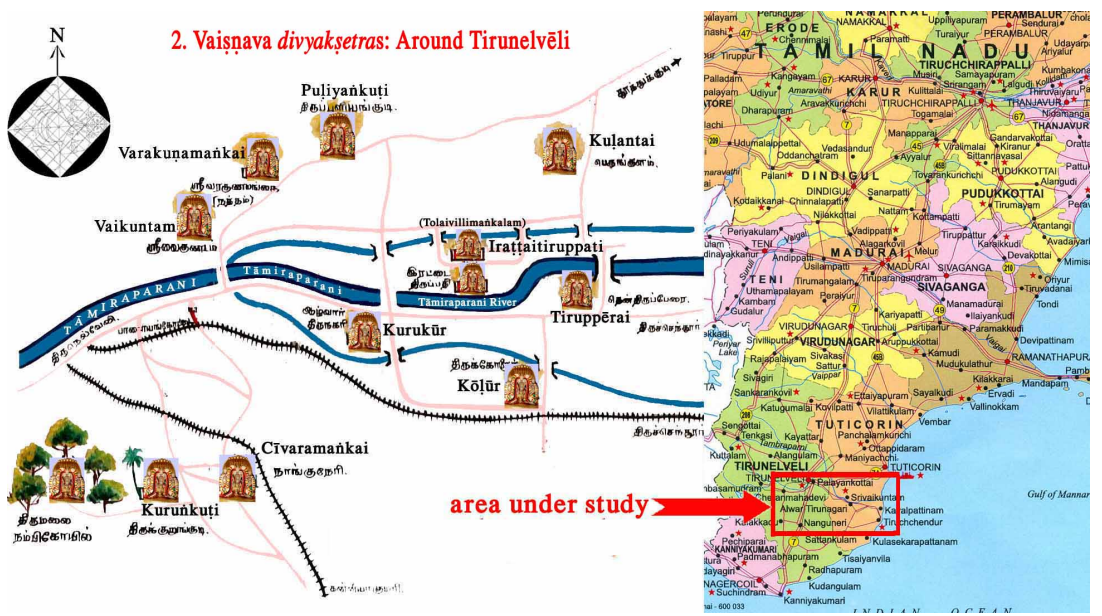

Map 0.2: Vaiṣnava divyakṣetras: Around Tirunelvēli.

The following house sthānaka-mūlaberas: Kurukūr, Tolaivillimankkalam, Vaikuntam and Kulantai. The following house àsana images: Cīvaramañkai, Tiruppērai or Tentiruppēreyil and Varakuṇaman̉kai. The following house sayana images: Puḷinkuṭi and Kōlūr. The Kurunkutit temple is extolled in the hymns of Malicai, Nam, Periya and Mankai. The mülabera is sthānaka. The total of sayana-mülaberas is four. The total of assana-mülaberas is five. The present study finds the total of sthānaka-mülaberas is nine. Sthānaka dominates the scene in the Pāṇinātu zone, followed by āsana and sayana. All the mülaberas are anthropomorphic. Zoomorphic or theriomorphic forms do not occur. The Ānaimalai cave temple, close to Mōkūr houses Nrsimha in its garbhagrha. ${ }^{7}$ This place is not counted under the divyadeśas. The Ādivarāha-Viṣnu-gṛha in Māmallapuram houses Varāhamūrti. The Kōvalūr temple houses Trivikrama. Such occurrences do not find shelter in the Pāṇdyan zone. In the pan-Indian context, out of the 108 divyakșetras 27 are äsana, 60 sthānaka and 27 sayana. Sthānaka-mūlaberas come first, followed by sayana and āsana (Ragunath 2005: Chap. I).

It may be pertinent now to examine what the $\bar{A} \underline{1}$ vārs have to say on each of the individual kṣetras in Pāṇ̣̣̄nāọu.

\footnotetext{
${ }^{7}$ Such images appear in the garbhagrha of the cave temples at Nāmakkal and Cinkaperumāḷōyil.
} 


\section{Māliruñcōlai}

The name Māliruñcōlai appears redundantly (T II 48, MOLI 2.10.1, 3, 5-10, ANT 4.1, 9.4,5, MPT 1.8.5, 2.7.7). Other forms of the name are Tirumāliruñcōlai (MOLI 10.7 all hymns), Teñtirumāliruñcōlai (PTM 4.2.1, 2, 4.2.7,8), Māyiruñcōlai (PTML 1. 249), Iruñcōlai (MPT 1.8.5), Malai (PTM 1.5.8), Ponmalai "Golden Hill" (PTM 4.2.3) and Tirumalai "Sacred Hill" (MOLI 2.4.10). The temple of the Lord is called Alakartankōyil "Temple of the Handsome Lord" (MOLI 2.10.2). This phrase gives clue to the present name of the place that is called Alakarkōyil. The temple was big, Perunkōyil (MOLI 2.10.9). The Lord is supposed to be seated, vitrirunta (PTM 4.2.10) or standing, ningray (PTM 5.3.1, ANT 9.4,5, MPT 9.9.3, 4-7). It is the place where the Lord is pleased to slumber, pallikollumitam (ANT 4.1). The present mūlabera is sthānaka and east facing (see fig. 1).

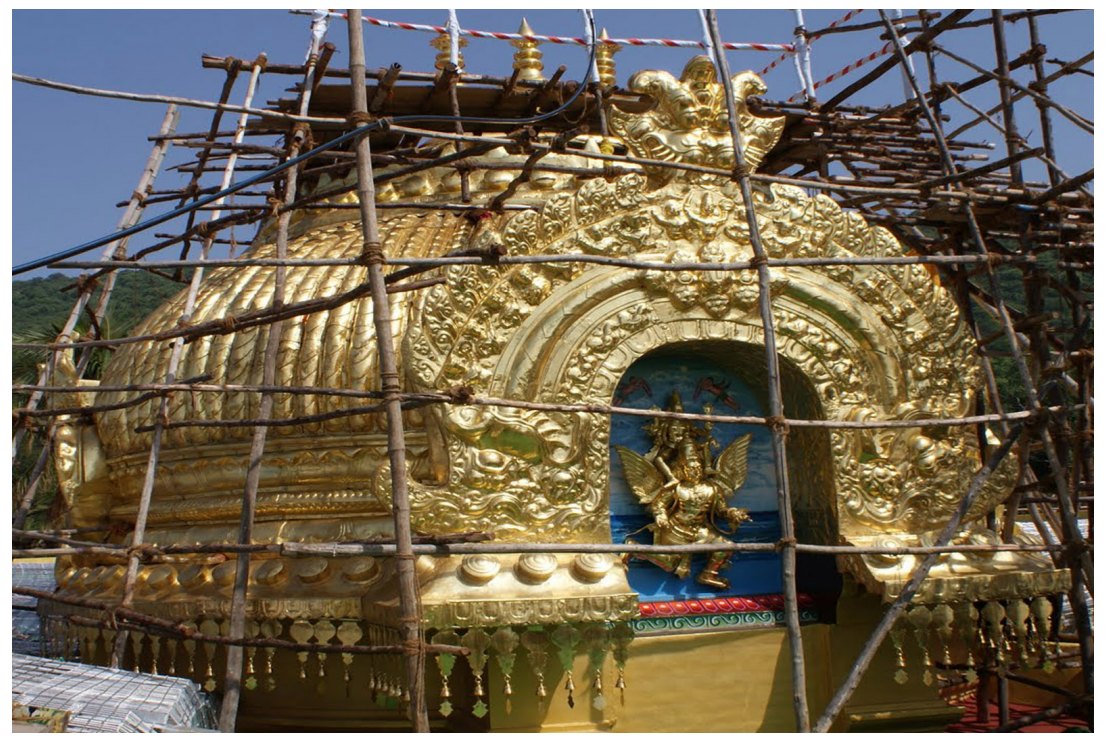

Figure 1: Gold-cast vimana of Māliruñcōlai (recent work).

Periyālvār's three eloquent hymns on the kṣetra are worth quoting:

... Alakanalàikāranmalai

Kulamalai kolamalai kulirmāmalai korramalai

Nilamalai nīnțamalai Tirumāliruñcōlaìatēe (PTM 4.3.5) 
"... It is the hill of the decorated handsome (Lord),

The clan-hill, bedecked-hill, the great frigid-hill, Sovereign-hill, Hill on earth, long-hill, this is the grove where Tirumāl resides."

Āyirantōl parappi mutịyāyiraminnnilaka Áyirampaintalaiya anantacayanañālummalai

Āyiramārukaluñ cunaikal palavāyiramum

Āyiram pūmpolilumuțai Māliruñcōlaiyatēe (PTM 4.3.10).

"His 1000-shoulders spread out, his 1000 tiaras shine and shine, $\mathrm{He}$ is ruler of the hill who (reclines) on the 1000-headed Ananta, There are 1000 s of rivers, several 1000 s of ponds, And 1000 flowering lakes, this is Māliruñcōlai."

Māliruñcōlaiennnum malaiyuțaiyamalaiyai Nālirumūrttitannai nālvētakkatalamutai Mēliruñkarpakattai vētāntavilupporuḷin Mèliruntavilakkai vițtucittan virittanavēe (PTM 4.3.11)

"He is himself the hill who takes possession of the Hill upon which Māl resides,

He is himself the Aștamūrti, He is the ambrosia of the Ocean of Four Vedas, $\mathrm{He}$ is up above, the all-giving Kalpaka tree; He is the meaning of Vedānta,

He is the Lamp atop that Viṣnusiddha ${ }^{8}$ explains." 9

All resorts of Viṣnu are the abodes of nature's blessing with lush green groves. Pūtam initiates the nature-loving saga with the saying that at Māliruñcōlai mūnkil (bamboo, Bambusa arundinacea) trees shoots up above the skies (T II 48). It abounds in good many numbers of lakes (MOLI 2.10. 1, 3, 5-10). In view of the presence of the huge quantity of water, it is the Tiruppārkațal "Sacred Milk Ocean":

Tirumāliruñcōlaimalaiyē tiruppārkațal (MOLI 10.7.7)

"The Sacred Ocean of Milk is the Hill where Tirumāl abides."

\footnotetext{
${ }^{8}$ This is the Sanskritic name of Periyālvār in its Tamil form.

${ }^{9}$ The importance of Viṣnu as Aștamūrti has been elaborated (Rajarajan 2004: 86-91) in an article with special reference to this hymn.
} 
It is really a fascinating poetic visualization because at Arankam the venue falls in between two ocean-like rivers, the Kāviri and Kollițam, the blessing of nature's wonder. The same hymn adds, Tiruvēnikațam is the veritable Vaikuntha:

Tirumāl vaikuntamē tantiruvēṅkațam.

It is because Vēnkatam lies on the top of seven hills, saptagiri, comparable to the mythical Meru. The lakes are full of flowers since the lotus plants fill the venue (cunaiyil centammarai ANT 9.5). The flowers generate a rhythm of scented smell (narumalar ANT 9.4). The pleasant breeze moves gently, arousing a sweet aroma (tenral manam kamalum ANT 9.7). The rich flora and fauna add a classical charm to the venue. Birds such as cuckoo, peacock (kuyil mayil ANT 9.4), cluster of bees (vantinam ANT 9.5) and a gana of black birds (kariya kuruvikkanainkal ANT 9.8) make their presence felt. They sing the praise of the arrival of Māl (Mālin varavu colli pātu ANT 9.8).

The presence of perennial water is due to not only the poor monsoon but also a river that cuts across the hills. It takes its origin on top of the hill in an artesian well and flows downward. Even today, the flow of water does not stop during the acute summer. The river is called nūpura(anklet)-Gañgā, Cilampāru in Tamil "Anklet River" (PTM 4.2.1, 4.3.9, ANT 9,10, MPT 4.9.9). The river does not flow with water but honey (tênāru pāyum PTM 4.2.4).

The Lord is invoked with eloquent nāmāvalis. He is Alakar "the Handsome" (MOLI 2.10.2), Skt. sundara or saundara "lovely [or] lively." 10 The other epithets are Māyavan "Illusionist" (MOLI 2.10.8), Tirumāl (MOLI 3.1.1), Nāanavētiyan "Wisdom-expert in the Scriptures" (MOLI 3.1.11), Parañcōti "Eternal Light" (MOLI 3.1.23), Kōvintan-Govinda (MOLI 3.1.3), Kaḷan-Māyan "BurglarIllusionist" (MOLI 10.7.1), Tennnan "Southerner" (MOLI 10.7.3), ${ }^{11}$

Ūlimutalvan "the First-born Primordial" (MOLI 10.7.9), Elicaiyincuvai "Melody of the Seven Music" (MOLI 10.8.2), Cōlaimalai-aracu "King of Hill of Groves" (PTM 1.5.8), Maṇivaṇnanan "Gem-coloured" (PTM 4.3.2) or Māmaṇivaṇnann (MPT 9.8.10), Kaṭalvaṇṇan "Sea-coloured (blue)" (PTM 4.3.3), Nampi (ANT 9.3),

\footnotetext{
${ }^{10}$ Today the Lord is called Saundararāja "King of Loveliness".

${ }^{11}$ It is a favourite epithet of the Pāndya.
} 
Cuntaran (Skt. Sundara [supra], ANT 9.10), Māyan (Skt. Māyā or T. Māyī; ${ }^{12}$ MPT 2.7.7, 7.9.7, PTML 1. 249), Karumāṇikkamāmalai "Great Hill of a Black-gem" (MPT 9.9.3), Mūvarilmunmutalvan "First and foremost among the Three (the Trimūrtis)" (MPT 9.9.1), Kōvalarkōvintan (Skt. Gopāla-Govinda MPT 9.9.1), Mutalmūrtti "Lord First" (MPT 9.9.2), Vānavarkōn "King of the Celestials" (MPT 9.9.5), Antarkō "King of those in the Cosmos" (MPT 9.9.3-7), Kēcavanampi (Skt. Keśavanambi (MPT 9.9.6) and so on.

Several mythological events are associated with the Lord. To note briefly at random:

He lifted the big hill, perumalaietuttān, Govardhandhāri (MOLI 2.10.4);

He eats the butter from the pots, uriyamar vennai untavan (MOLI 2.10.6);

He mounted the bird, Garuda, pullūrntu (MOLI 3.1.9);

$\mathrm{He}$ ordains all the worlds, punishes, eats and vomits ulakellamm pațaitițantuntumilintāy (MOLI 3.1.10);

Śiva ${ }^{13}$ and Brahma ${ }^{-14}$ attend on him (MOLI 3.1.10, 10.7.7, PTM 5.3.6); He took into service a monkey (Sugriva) and did away with the life another monkey (Vāli), oruvāranam panikonțu oruvaranam uyirunțān (PTM 4.2.5);

He recovered Rukmiṇī (and married her), Uruppiṇ̄ nankai mịtțān (PTM 4.3.1);

He did away with Kañcan (Kamsa), Kāliyan (Kāliyamardana), kalịu (the elephant, Kuvalayapịa), marutu (toppling the trees, Yamalārjunabhanga) and erutu (the bull, Dhenukāsura-vadham) (PTM 4.3.2);

Lord of Dvārakā, Tuvarāpatiemperumān $($ ANT 9.8);

\footnotetext{
${ }^{12}$ These three are very popular personal names among the Piramalai-kallar people who live in the region around Maturai. The Kallar in the Tañcāvūr region hold Tirumankkai-ālvār in high esteem and observe a fast (by not taking non-vegetarian food) in the Tamil month of Purațtāci (September-October), holy to Viṣnu, especially Vēnkatéśvara as his brahmotsava takes place in this month at Tirupati-Tirumala, the cherished Vēnikatam.

${ }^{13}$ Śiva is called Piraiyêrucataiyan "He with matted locks of hair that bears the crescent" (MOLI 3.1.10), Mukkannan "three-eyed" (MOLI 10.7.7) and Erutukkotiyān "holder of the banner of bull" (PTM 5.3.6).

${ }^{14}$ Brahmā is called Nānmukan "the four-faced" (MOLI 3.1.10) and Piraman (MOLI 10.7.7, PTM 5.3.6).
} 
The Dwarf who elongated as Trivikrama, Kuralāynimirnta tirivikkiraman, (MTM 9.9.5);

Born in north Madhurā, Vațamaturaippirantān (MTM 9.9.6); Dancing bird, àtarparavai (infra, cf. Kalidos 1999a: 229) (MPT 9.9.10) and so on.

Another important dimension of the mythical accounts is that the Lord is supposed to have presented the kutakküttu "pot-dance" and the dancer is called Küttan (cf. Kalidos 1999a), Kuțankalantātik kuravai munkōtta kūttavemmațikal "Dignified Dancer" (Națeśvara? MPT 9.8.6), cf. àtarparvai (supra).

The rituals, services, nityapüjās and utsavas that took place on the venue are described graphically:

Damsels present their dance recitals, teyvamakalirātum (PTM 4.2.1);

The kuratti damsels (hill-folk, gypsies) cultivate the dance, kuramātar natampayil (PTM 4.3.4);

The a yyar sing and dance his praise (PTM 3.4.5) that recalls the Aycciyarkuravai of Cîlappatikāram;

The festivities were instituted by the cowherds, àyarkūți amaittavila $\bar{a}$ (PTM 4.2.4);

Nețumāran, the King of Kūțal, celebrates the Lord, Nețumāran tenkūtark

The six-legged bees recite the 1000 names and sing the Lord's glory early in the morning, arukālavanținañkal āyiranāmañcolli cirukālaip pātum (PTM 4.2.8);

The bhütas (mass) offer red-blood and conduct the evening bali, ${ }^{15}$ ceṅkurutikontu pütankal antippalikotuttu (PTM 4.2.9);

The food offering included 1000 pots of butter and 1000 pots of a sweet dish called akkāravațicil ${ }^{16}$ (ANT 9.6).

From the above account, it is quite clear the cult orientation of the Māliruñcōlai temple gets back to the 4th century $\mathrm{AD}$ and today it continues to be a living tradition. There could have been some setback during the days of Islamic depredation in the 14th century and after as

\footnotetext{
${ }^{15}$ The author (Rajarajan 2006: 15) has noted the non-vegetarian food served in the Mannnārkuți temple, a divyakșetra in Cōlanāḍu. In addition to chicken, several varieties of cooked birds and fishes were offered.

${ }^{16} \mathrm{It}$ is delicious sweet rice, now available in a hotel on the south gate of the temple at Śrīrangam.
} 
some destroyed mandapas are found within the present temple complex and the fact that the present temple in its entirety was the outcome of the Vijayanagara-Nāyaka period (Rajarajan 1995) and no trace of pre-Vijayanagara architecture is present, excepting the literary clues.

\section{Kōttiyūur}

Since the ksetra figures in the hymns of Pūtam and Pēy, it is clear the antiquity of the temple gets back to the later 5th or early 6th century AD. Others to extol the place are Malicai, Periya and Mankai. The place is called Tirukkōtṭi (T II 46, 87, PTM 4.4.5), Kōṭtiyūr (NTV 34, PTM 1.1.1, 2.6.2, MPT 10.1.9, PTML 1. 250) and Tirukkōțtiyūr (PTM 1.1.10, 4.4.1, 4.4.1, 3-4, MPT 7.1.3). The Lord is called Kōttiyar (PAL 11) and Kōttịūrān (MPT 9.10 all hymns), He of Kōttị. He is Maṇivaṇnan (PTM 4.4.2), Tirumālavañ (PTM 4.4.3), Naraciñkan/Nṛsiṃha (PTM 4.4.6, 9), Kōvintan̄/Govinda (PTM 4.4.8), Kēcavan_/Keśava, Puruțottamañ/ Puruṣottama, Kunal "Dwarf” (PTM 4.4.10), Iruțikēcañ/Hṛșkeśa (PTM 4.4.11), Nețiyān “the Tall” (MPT 9.10.5) and so on. He is viewed as a dancer, kuraikalar-Küttan who wears the anklets (PTM 10.1.9). Nothing regarding stance of the Lord is said. It is simply added that the Lord resides, uraikingra (PTM 4.4.8). It may note that the vimanna is aștanga today, housing the āsana, sthānaka and sayana images in its three vertical tiers. The temple is east facing. The utsavabera is sthānaka (see fig. 2).

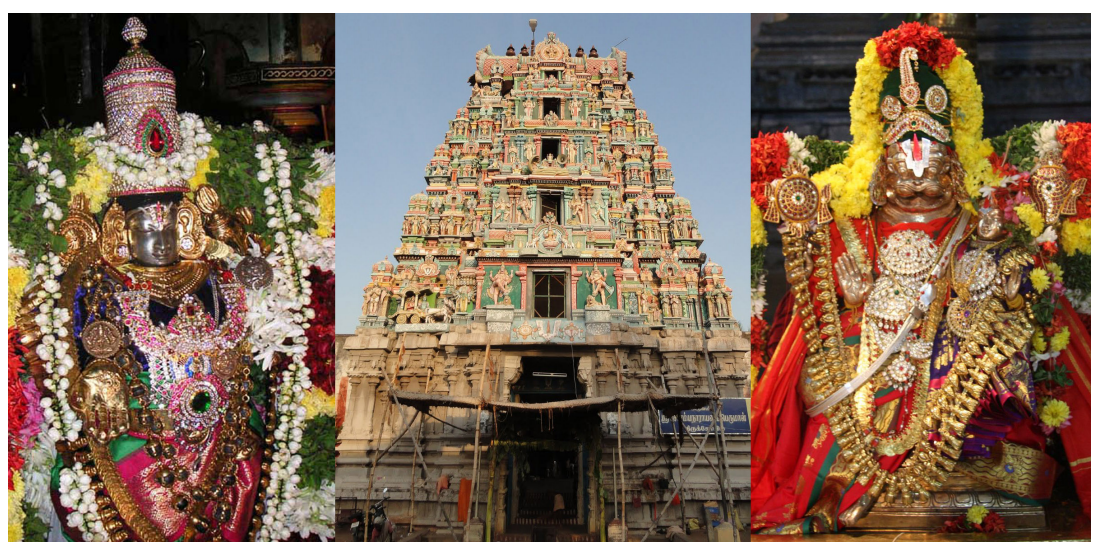

Figure 2: Kōtțiyur, utsavaberas. 
The kșetra was surrounded by groves, anitikalum cōlai (T II 46). Again, it was full of fertile paddy fields (PTM 1.1.10). Red lotuses abounded in the fields, cenkamalavayal (PTM 4.4.4). The city all the time felt the nice smell of jasmine and other scented flowers, mullai (Jasminum auriculatum) mallikai manakkum (PTM 9.10.7). It was full of tanks, nirttirukkottti (PTM 4.4.5). It is an arankam "stage (for dance)" where the Lord cultivates dance, payinratarankam (T II 46). The city was filled with palatial building, mätankalcū 1.1.1). Though in the plains, the mystic finds it a sea or hill, katale malaiye tirukōttiyyūrēe (MTM 7.1.3).

Few of the purānic episodes are associated with Lord. It was he whose foot measured the worlds, alantatiruvati (T II 87). He is the Lord who moves everywhere by leaps, plays and dances: énkuntirintu vilaiyattum (PTM 2.6.2). He is the one who gulped the seven worlds, yelulakunța (PTM 4.4.2). He willingly offered half his body to Śiva and thus became Harihara, İcarkicaintu utampilōr kūrutān kotuttān (MPT 9.10.4). He is pleasing to Śrīdevī, Tirumāmakațkiniyān (MPT 9.10.2). He was the dancer who plucked the tusk of an elephant, Kuvalayapīḍa. While enacting such a heroic feat, the Lord performs a dance, kuraikalarkūttan (MPT 10.1.9). He lifted the mountain and protected the world form the rains, māmalai ningru kāttukantān (MPT 9.10.7). His tiara was high, nīnmuți (MPT 9.10.5).

The cult orientation is specified. It is a known fact that the kṣetra in a later date was linked with Rāmānujācārya who is said to have gone to top of the temple and uttered the aștakssara, the eightsyllabled mantra, so that every one, including the pañcama, could utter it. ${ }^{17}$ It was a brahmadeya with large settlement of brāhmanas. Periyālvār, himself a brāhmaṇa, avers the place was full of those who study the Vedas for making a livelihood, vêtampayinruvāl (PTM 4.4.1). The experts in the four Vedas extol the praise of the Lord day and night and live here, nānnmaraiyōrirāppakal ètti vāl Tirukkōttiyyūr (PTM 4.4.7). Those wearing the purinül/yajñopavita sing the Tamil and dance the kutam. This may confirm the fact that intra-sectarian tug-of-war such as vatakalai-tenkalai did not peep into the pictur at

\footnotetext{
${ }^{17}$ It was part of the vatakalai-tenkalai rivalry. According to the orthodox vatakalais (Northern Order) the brāhmanas alone were entitled to mutter the sacred aștâkșara (Om Na Mo Nā Rā Ya N̦ā Ya) who depend on the Sanskritic Vedas and purānas. The tenkalais (Southern Order) held any lover of Viṣnu could utter the sacred mantra who depend on the Tamil Veda, the Nāläyiram.
} 
that time since they gave equal importance to Tamil and Sanskrit. The experts in Vedas perform the five kinds of veelvi/yajña, nānmaraivānarar...aivakaivēẹtvi (MPT 9.10.9).

\section{Pullāni}

Mañkai has two patikams on the kșetra (MPT 9. 3, 4). The place name is Pullāni (MPT 9.3-4 passim). The Lord is called Pullānittennnan "Southerner at Pullānii" (PTML. 11. 261-62) and Māyan-maṇivaṇnan (MPT 9.3.6). Nothing is told of the Lord's stance. Today the mülabera is seated and east facing (see fig. 3).

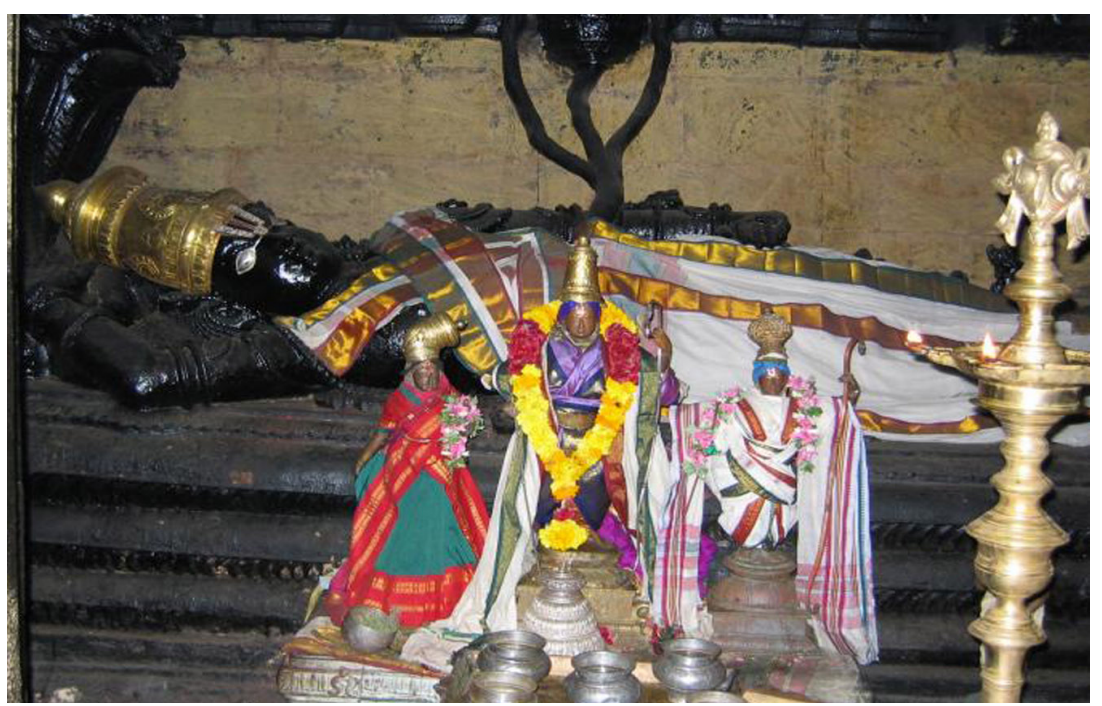

Figure 3: Pullāni, mūlabera and utsavabera.

The Ālvārs' description mainly concentrates on the ecological setting of the venue. Pullāni is beautiful, abounding with punnai (Colophyllum inophyllum) plants ${ }^{18}$ and ponds that yield pearl, punnai muttam polil culntu alakāya pullāniye (MPT 9.3.1). The fact that the venue was full of lakes and ponds are affirmed again and again (9.3.2-5). The ponds are called variously as tatam or tatăkam (MPT 9.3.3), nìr (MPT 9.3.2), palananam 9.3.6) and polil (MPT 9.3.10). Black bees hum about the flowering water sources, karivanținam pātum

${ }^{18}$ This plant sheds flowers that arouse carnal feelings. 
(MPT 9.3.8). The ponds teem with pearls, corals and enchanting lotuses (MPT 9.3.1). Gold sediments are found (MPT 9.4.8). The urban status of the venue is attested with reference to the palatial structures on the site, manimātappullāni (MPT 9.4.7).

Rarely few mythological scenes are alluded. The Lord came as a Dwarf and conquered the worlds in three steps, kuraluruvāy müvatimankonta (MPT 9.4.2). That he cleaved Hiranya, having comes a lion, Iraniyan...Ariyuruvāykkințān (MPT 9.4.4). The presence of brähmanas is affirmed because the Vedas and velvis were cultivated incessantly (MPT 9.4.9-10).

\section{Meyyam}

Figuring in the hymns of Mankai, the place is called Meyyam (MPT 2.5.8, 5.5.2, 6.2.3, 10.1.5, 11.7.5, TKT 19) or Tirumeyyam (MPT 3.6.9). The Lord is Tirumeyya-malaiyālan (MPT 3.6.9) or Meyyamalaiyālann, meaning ruler of the Meyyam hill. Mey means "body". Mey also means "truth" and so the epithet gives the meaning "Lord Truth". Talking of the Lord at Māliruñcōlai, Periyālvār says "He is not true to anybody", nī yoruvarkkum meyyanallai (MPT 5.3.2). ${ }^{19}$ These epithets would contextually suggest that the hill itself is an abstraction of the Lord's body. Therefore, the Lord is Meyyān and Meyyamalaiyann (MPT 11.7.5). The Lord is said to be in the reclining mode, tatavaraimēl kitantān (MPT 2.5.8). The mystic says he is gratified for having seen the Lord in such a tranquilizing slumbering

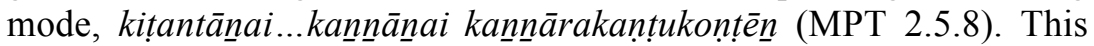
phrase suggests that the Lord is dear to him as the eyes, kannannai, thereby opening an avenue to explore the meaning of the darling Tamil name Kaṇnan, which means "one dear to the eyes." The Lord is also said to be in seated mode, Meyyamarnta-perumān (MPT 6.8.7). The hint to the reclining mode is definitely to the rock-cut image. The note on seated mode would suggest that by about the time of Mankai some structural addition, housing a seated image of the Lord is likely to have ushered into the scene. Today the mulabera in the structural temple is sthannaka and in the cave temple a sayanabera (see fig. 4).

\footnotetext{
${ }^{19}$ Why? It is because he had to resort to foul means under certain compelling circumstances to overcome evil forces; e.g. deception of Mahābali, dislodging Vāli, killing Duryodhana and so on. The way he decepted Mahābali forces Namālvār to call the Lord a cheat, vañcan (MOLI 3.8.2, cf. Kalidos 2006: 8).
} 
Meyyam was full of water resources; punalcūlnta Meyyam (MPT 2.5.8) and today the visitor may find an ocean-like concourse of water close to the hill, especially during the monsoon.

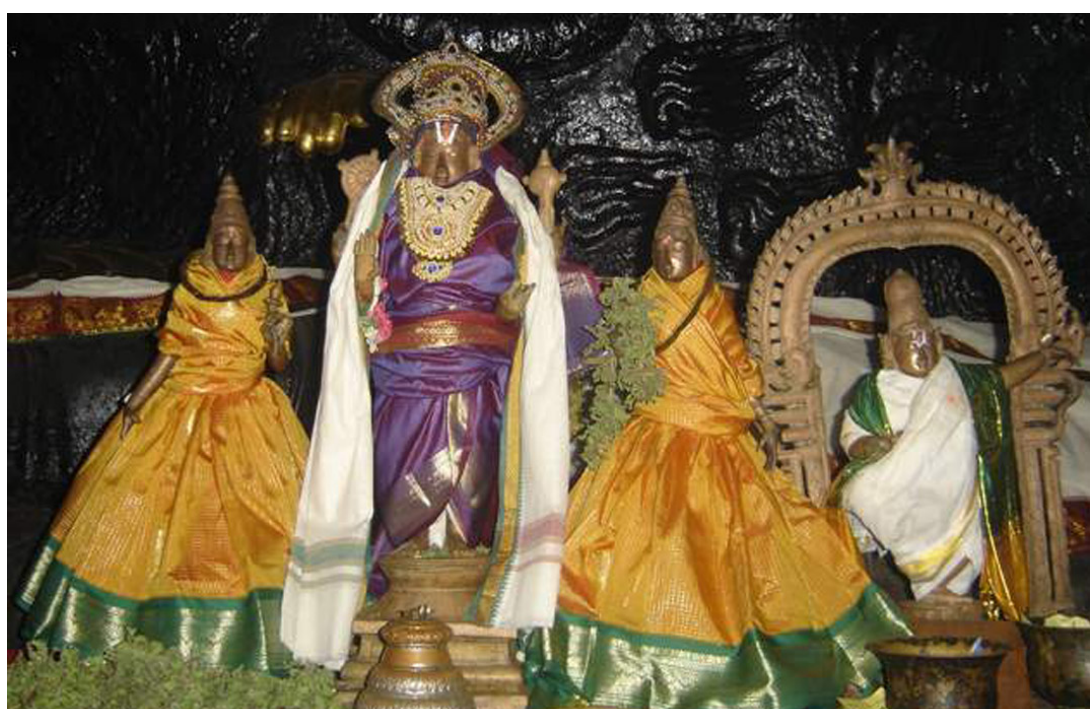

Figure 4: Meyyam, utsavabera in rock cut cave.

Few references underline the mythological setting of the ksetra. The Lord came as a damsel and coveted the ambrosia that denotes the Mohinī amśấvatāra (MPT 2.5.8). He is said to have increased as a fierce lion, Siṃha or Nṛsiṃha, ațalariyāy perukin̄ān (MPT 2.5.8). He was chiefly instrumental in setting fire to the Kāndava forest as a prelude to the Mahābhārata war, kāntavattai tīmūtți (MPT 6.8.7). He was the Lord who annulled the imprecation on Siva who was wandering at others houses a mendicant, holding the begging skull in a hand and eating, mantaiyētip pirañmanai tirintunnumum unțiyān cāpam tìrttu (TKT 19). He was the chief of the gods, vānavartam talaivan (MPT 5.5.2). His mien was dark as the collirum-like sea, black hill, rain-drenched cloud, the kuvalai (blue lily, Nymphaea nouchalia) flower and kāya (Memecylon edule) flower, maiyārkatalum manivaraiyum māmukilum/ koyyārkuvalaiyum kāyāvum pōṇrirunța (MPT 11.7.5). Today if you look at the image of Śeșaśāyi in the rockcut cave the depth of this statement could be understood (Kalidos 2006: Pl. III) because the pale pink coloured rock-cut image is made 
dark as collirum by the application of herbal stuff during abhișeka on the image.

\section{Tankāl}

Talking of Taṇkāl, Pūtam says the Lord's residences are at Tañcai, Aran̉km, Taṇkāl, Māmallai (Māmallapuram), Kōval (Kōvalūr) and Kuṭantai (Kuṃbhakoṇam) (T II 70). The place name is Taṇkāl (T II 70, CTML 1, 141, PTML , TNT 17) or Tiruttankāl (MPT 5.6.2). The Lord is Tirutankālūran "He of Tiruttankāll" (MPT 5.6.2). The people sing and dance the praise of the Lord (TNT 17). Nothing is told of the Lord's stance. The mülabera in the structural temple is sthanaka and sayana in the cave temple (see fig. 5).

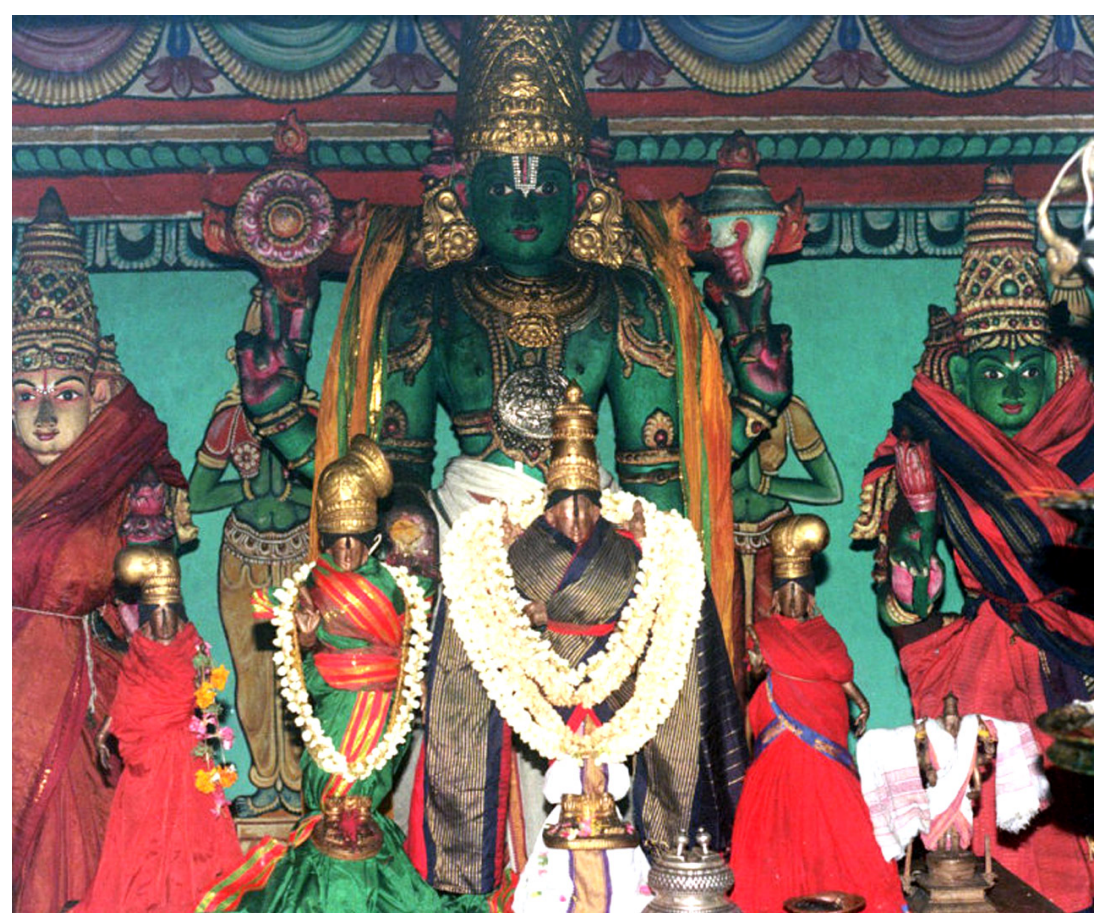

Figure 5: Taṇkāl, mūlabera and utsavabera in structural temple. 


\section{$M \bar{o} k \bar{u} r$}

The place name is Tirumōkūr (MOLI 10.1.1, 4, 7, 10, CTML 1. 147). The Lord's names are 1000, a clue to sahasranama. He is reclining on a snake, pāmpanai pallikolvān (MOLI 10.1.4). His name is Kālamēkam. Today the Lord is called Kālamēkap Perumāḷ. The mülabera is sthannaka (see fig. 6). The place is surrounded by fertile fields, valavayalcū (MOLI 10.1.7). The fields in eight directions are full of fishes where rice and sugarcane grow, enticaiyu min karumpōtu peruñcennelvilaiya (MOLI 10.1.5). The Lord's eyes are lotus-like or flower-like and the mouth fruit-like or coral-like, kamalakkan kanivāy (MOLI 10.1.1), malarkkan pavalaccevvāy (MOLI 10.1.9).

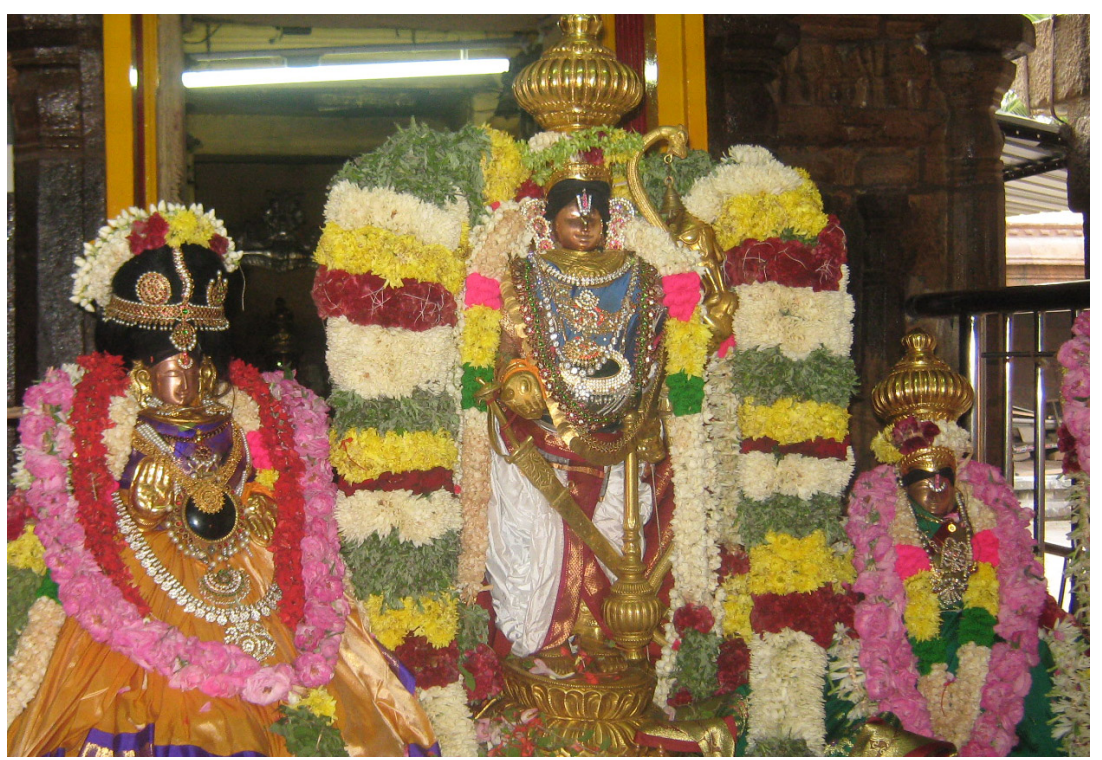

Figure 6: Mōkūr, utsavabera.

Few mythological events are linked with the kșetra. He measured the three words, antamüvulakalantavan (MOLI 10.1.5). He destroys the demons by taking a lascivious form, i.e. Mohinī, vallacurarai... kāmarūpañkonțu eluntalippān (MOLI 10.1.10). He destroys the three worlds in the presence of Brahmā, Siva and the gods, Nānnmukan aran̄oțu têvarkal nātạ/mūvulakalittu (MOLI 10.1.3). Few references notify the dancing aspect of the Lord. The Lord is Küttan-Kōvalan, dancer-cowboy (MOLI 10.1.7). He is the Dancer 
who performs the pot, kutamattuküttan (MOLI 10.1.11). The dance recital by the Lord was so ecstatic that the devotees were enamoured to imitate him by presenting an orgiastic group dance by circumambulating the temple, kōyil valañceytu ikkātutum kūttē (MOLI 10.1.5, cf. Kalidos 1999: 232). The venue abounds in the presence of the experts in scriptures, maraivannarvāl (MOLI 10.1.2). This is to attest the cultivation of the Vedas and the sacrifices.

\section{Kütal}

Mankai alone has a rare reference to the place that names the venue Kūtal (MPT 9.2.5). The Lord himself is a gopa, kōvalarēoppar. He holds the śankha and cakra. His lips are coral-like, and the body is a coral hill, pavalakkuñru (MPT 9.2.5). The vimāna of the Kūtal Alakar temple is aștànga and houses all three stances in its three vertial tiers. The ground floor houses a seated mülabera (see fig. 7).

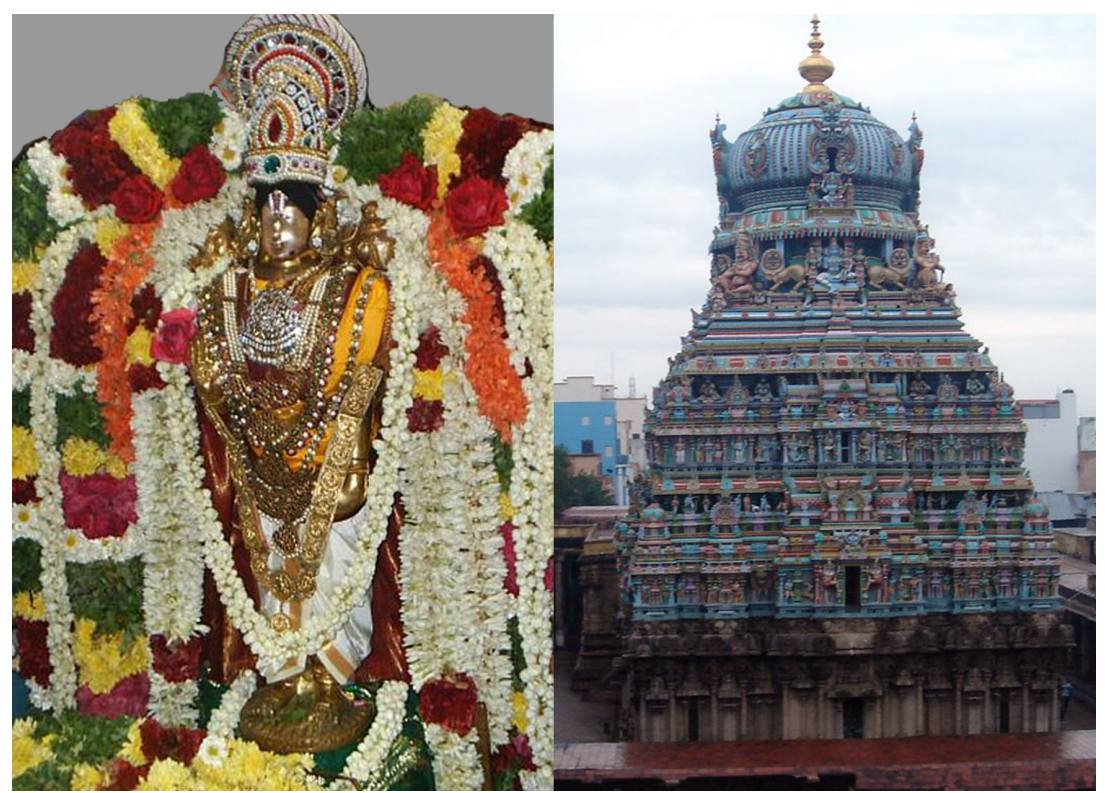

Figure 7: Kütal, utsavabera and the rear view of the vimana.

Periyālvār is supposed to have composed his Tiruppallānțu at Kūtal, especially in the Kūṭal Alakar temple. Scholars are of opinion that there is no authentic evidence to prove this fact. However, the 
Great (Periya) Ālvār refers to Tirumaturai (Tiruppallānțu v. 10) where Rāma bent the bow (? [Mithilā] to take the hand of Śitāa) and pounced on the five-hooded cobra (Kāliyamardana), tiru maturaiyul/cilai kunittu aitalaiya painnākat talai pāyntavañ. It may be an indirect clue to the composition of the hymns at Maturai/Kūtal. It may also note that Maturai in this reference is believed to refer to Mathurā in the north. It need not be so. There is no positive clue to this assumption.

The Tiruppallanțtu is the most sacred among the hymns of the Ālvārs that extols the praise of the Lord's sacred feet for several years, several more years, several thousands of years and several thousands of millions of years:

Pallāṇtu pallānțu pallāyirattānțtu palakōti nūūāyiram Mallānța tinntōl Maṇivanṇā un cēvațicevvit tirukkāppu (v. 1)

It is the most sacred of the hymns that extols the praise of not only the Lord Viṣnu but also his consort:

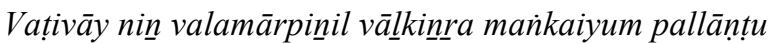
...cuțar āliyum pallānțtu ...ap pāñ̃cacannniyamum pallānțu (v. 2).

"Let the Maid who resides in your right chest (Śrīvatsa) be extolled for several years... the shining disc for several years... and the Pañcajanya (conch) for several years."

The other hymns extol the praise of the Lord for pallāntu "several more years":

Pallântu to the Lord who toppled the flanks of the demons of Lañkā v. 3.

Pallāntutu to all those that sing the praise of Nārāyaṇa v. 4.

Pallāntu to those that mutter the Lord's sahasranamma v. 5.

Pallāntu to the Lion (Nrsimha) who slaughtered a lion-like demon, Hiranya v. 6.

Pallạntu to the Lord who overcame the demon, Bakāsura v. 7.

Pallāntu to the enemy of snakes, Garuda v. 8.

Pallāntu to the Lord who reclines on the snake at the time of tiruvōnam festival v. 9.

Pallạtutu to the Lord who pounced on the five hoods of a demonsnake, Kāliya v. 10 
Pallāntu to the Lord's devotees who mutter the aștākșara with devotion v. 11.

Extol the pallānțu to the Lord of pallānțu v. 12.

Even though the data on Kūṭal is less, the Pallānțtu adds to its credit.

\section{Villiputtūr}

Periyālvār and Ānțāl have only two hymns on Villiputtūr. ${ }^{20}$ The Lord is pleased to be seated when damsels play a melodious music. The Great Ālvār eloquently says what a penance his mother should have undertaken to beget him as her son, empirān nu piranta pinnnailettannaiyum ceyyapprrāay (PTM 2.2.6). Āṇțāl says the Lord resides at Villiputtūr, villiputtūruraivān (ANT 5.5). Uraivan (urai literally "freeze") is likely to denote the reclining Lord. The Lord was a bedecked parrot that was fed with milk-rice. He skipped the worlds as Trivikrama. Today the mulabera in the temple is in sayana mode (see fig. 8).

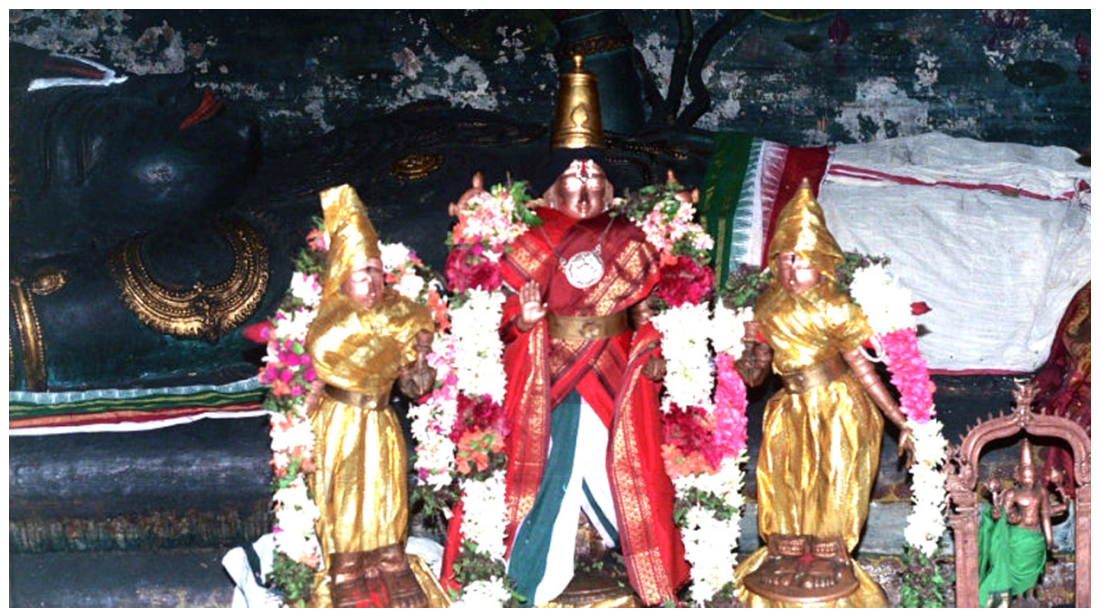

Figure 8: Villiputtūr, mūlabera and utsavaberas Vatapatrasayi and Antal.

\footnotetext{
${ }^{20}$ I (R.K.K. Rajarajan) first visited the place with my father (Prof. Raju Kalidos) and Prof. Vidya Dehejia when a school going boy at the age of 15 . It was this visit that aroused in me a curiosity to select art history for higher studies that finally honoured me with the Alexander von Humbolt post-doctoral Fellow at Berlin.
} 
Ānțāl composed the Tiruppavai at Villiputtūr for the sake maidens (T. pa avais) to cultivate a fasting in favour of the Lord and take a good husband. Anntạạ's dream was to take the hand of Māl/Viṣnu himself, much more erotically (Friedhelm Hardy's virahabhakti) adumbrated in the Nācciyār Tirumoli (Kalidos 1997: 117-38). Though the scene of Ānțâl!'s dreams are set in Āypāṭi (Mathurā) and Tuvārakai (Dvārakā), the actual scene falls within the bounds of Villiputtūr. ${ }^{21}$ Therefore, all the 30 hymns of Tiruppāvai may be counted under the kșetra Villiputtūr.

\section{Kurukūr}

Kurukūr (today's Ālvārtirunakari) has gone deep in the Vaiṣnava matrix of the Tamil country as the birthplace of Nammālvār. He has no mania to adumbrate the glories of his nativity, as it was the case with Periyālvāar and Āṇtạạ. Nam has a patikam MOLI 4.10 on the ksetra. The place name is Tirukkurukūr (MOLI 4.10 all hymns). Today the mülabera is sthannaka. The beautiful venue was full of palatial buildings, proclaiming its urban status, manimāța nịtu Tirukkurukūr (MOLI 4.10.1), mātamạ̣̄̄ikai cūlntalakāya (MOLI

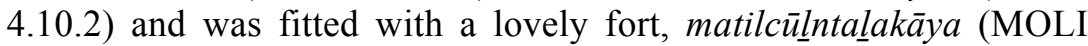
4.10.4). The Ālvār is nostalgic of the beauty of the place, alakāya (infra). The place was full of muddy fields in which paddy and lotus blossoms, cêrril cennel kamala mōinkum (MOLI 4.10.7). Palm trees surrounded the venue that decorated it, vēnuvanam (vēnu "bamboo"?), panai culntalakāya (MOLI 4.10.9). Paddy and sugarcane grew richly tall in that fertile soil, cennel karumpōtōònku (MOLI 4.10.10).

The Lord is called Ātimūrtti (Skt. Ādimūrti MOLI 4.10.7). Today the presiding God is called Ādinātha. He is the Kuțakkūttan, one who performs the kutakküttu (MOLI 4.10.10). He is said to be seated or standing, amar (MOLI 4.10.9) or nirka (MOLI 4.10.10). He is the creator who ordained the gods, the worlds, Nānmukan and all the living organisms (MOLI 4.10.1). He created all and at the same time swallowed and spit the same, pataittu anrutane viluniki/karantumilntu (MOLI 4.10.3). He is the Nāyaka of Brahmā and Civan/Śiva (MOLI 4.10.4). Let the experts in Linga Purāna, Jains and Buddhists deliberately debate with him (regarding the high status of their cults) but he is the Lord of all, ilinkattitța purānattīrum

\footnotetext{
${ }^{21}$ For an analysis of the Tiruppāvai see Kalidos 2006: 84-9.
} 
camanum cākkiyarum valintu vātu ceyvīr (MOLI 4.10.5). ${ }^{22} \mathrm{He}$ is himself the six-religions, arucamayam avaiyāki and was himself the Ādibrahmā (MOLI 4.10.9). Nārāyana is the Ultimate God who blessed Mārkaṇḍeya (MOLI 4.10.8).

\section{Tolaivillimanikalam}

Today's name Tollaivillimañkalam is a meaninglessly corrupt jargon; tolai means "distant" or "far away" and tollai "trouble" or "disturbance". Nam has a patikam 6.5 in MOLI on the ksetra. The place name is Tolaivillimankkalam (e.g. 6.5.1,4). The place was on the northern bank (of the River Tāmiraparani), vațakarai (MOLI 6.5.6, 8). The Lord is called Tēvatēvapirān (Skt. Devadevamūrti MOLI 6.5.2), Tevapirān̄ (Skt. Devamūrti MOLI 6.5.11), Kalllapirān (MOLI 6.5.4),

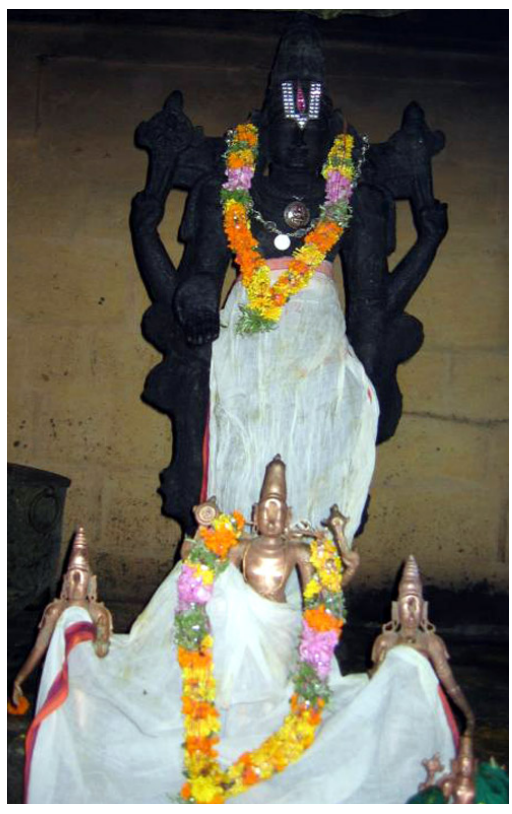

Figure 9: Tolaivillimankkalam, mūlabera and utsavabera.
Manivinạnan (MOLI 6.5.6, 9) and Mukilvannnan. Today the mülabera and utsavabera are sthānaka (see fig. 9).

The place was fitted with towering palatial buildings, māmaṇi mātamoñki (MOLI 6.5.1). It was full of ponds in which several flowers as if kuvalai (blue lily) blossomed (MOLI 6.5.1). It was also full of fields in which paddy, sugarcane and red lotus grew abundantly, karumpōtu cennellōìku centāmarai (MOLI 6.5.6). Rarely the Lord's purānic līla is hinted: ticai ñălam tāviyalantu "He leaped and measured the directions and the worlds (as Trivikrama)" (MOLI 6.5.3). His consorts were the daughter of the earth and the

\footnotetext{
${ }^{22}$ Rival parties of various religious groups in India of those times engaged in vātu (Skt. tarka) to establish the supremay of one over the other. Here is a clear notation of sectarian dispute. Indian religions never engaged in armed conflicts as it happended in the West, e.g. the Crusades and Hundred Years or Thirty Years War, cf. today's protracted war between Israel and Palestine.
} 
auspicious maid, Śrī, nilamāmakal tirumakal (MOLI 6.5.10). Experts in the scriptures inhabited the kșetra, nānmaraivannar vā Tolaivillimankalam (MOLI 6.5.4). They fostered the refined Vedas and performed sacrifices, tiruntu vètamum vēlviyum (MOLI 6.5.8). All the time the noise of festive celebrations reverberated on the venue, vilavoli (MOLI 6.5.2).

\section{C̄̄varamañkai}

Nam has a patikam MOLI 5.7 on the kșêtra. The place is called Cīvaramañkai-nakar (Śrī -varada [boon offering] -mañkai [maid], MOLI 5.7.1, 3-4). The Lord is called Cīvaramankalanātar (MOLI 5.7.5), Vānamāmalai “the Celestial Big Hill” MOLI 5.7.6), Cīvaramañkaivānan (MOLI 5.7.8), Teyvanāyakan (Skt. Devanāyaka, "Hero of the Gods" MOLI 5.7.10, 11) and Tirivikkiraman (Skt. Trivikrama MOLI 5.7.11). The Lord is supposed to be seated, viñrirunta (MOLI 5.7.1,4) or irunta MOLI 5.7.9). Today the mülabera is seated and the utsvabera sthānaka. The Lord is invoked with other pet epithets such as Aravintan (the flower, aravida MOLI 5.7.1), Ammān (the Father, MOLI 5.7.1), Karumenniyammān (the black-hued Father, MOLI 5.7.5), Vānanāyakan (the celestial hero, MOLI 5.7.6), Manimānikkaccutar (light of the great black stone, MOLI 5.7.6) or Karumānikkaccutar (light of the black gem, MOLI 5.7.9), Vannavarkoluntu (sprout of the gods, MOLI 5.7.7) and Tāytantai (Mother-Father, MOLI 5.7.7). The Lord's attributes were the cañku (śankkha), cakkaram (cakra) and puțoti (pakșidvaja or Garudadvaja) (MOLI 5.7.2-3).

The ecological setting of the venue is told in few hymns. The muddy fields were full of lotus, paddy and sugarcane; cêrruttāmarai cennel (MOLI 5.7.1), karumpum cennelum (MOLI 5.7.11). The urban status of the venue is pointed out with reference to the gem-like palatial buildings, manimātam (MOLI 5.7.8).

Few references note the mythological setting. Krș̣na conducted an illusionary war to curb the pride of the 100 Gauravas, nürruvar mankka... māyappōr panni (MOLI 5.7.4). The Lord cleaved the mandibles of a bird, pullinvāypilanta (MOLI 5.7.8-9). He dislodged seven fierce bulls, erutēlațarnta (MOLI 5.7.9).

Cìvaramañkai was a sacred venue as it was inhabited by so many experts in Vedas, maraivallavar palarvā 
Vedas and yajñas were endlessly cultivated, vēta vēlviyarāa (MOLI $5.7 .4,7$ ) by the experts in the four Vedas, nānmarai vallār (MOLI 5.7.9).

\section{Tentiruppēreyil}

Nam has a patikam on the ksetra MOLI 7.3. The place name is Tiruppēreyil (pēreyil means "big fort", MOLI 7.3.1-2), now called Tiruppērai. The Lord is called Maṇivaṇnan-Kaṇnan (MOLI 7.3.2), Kaṇnapirān (MOLI 7.3.9) and Accutan (Skt. Achyuta MOLI 7.3.11). $\mathrm{He}$ is in the seated mode, vir rirunta (MOLI 7.3 all hymns). Today the mūlabera is seated (see fig. 10).

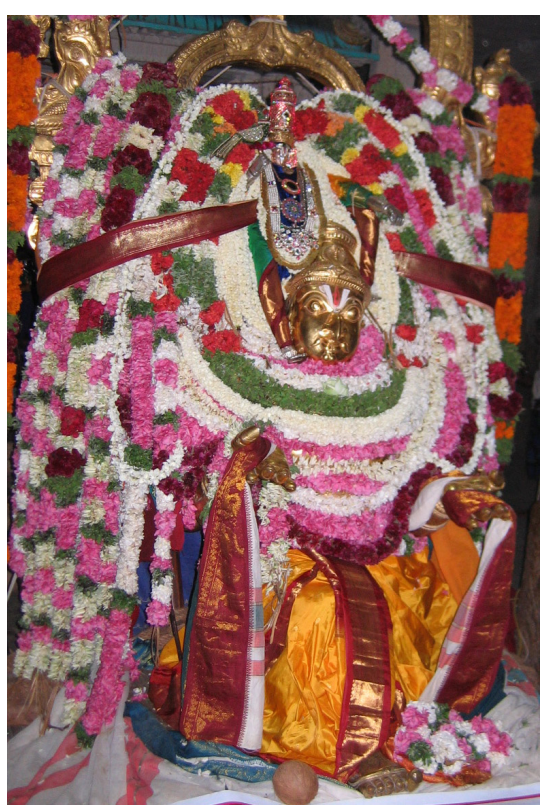

Figure 10: Tentirupēreyil, utsavabera on Garuda vahana.

Palm trees surrounded the place, tanpanaicūl (MOLI 7.3.2). Paddy plants in the fields toss like cāmaras, cennelkavari vīcum (MOLI 7.3.6). Towering buildings added an urban status to the venue, cikaramani netumātam (MOLI 7.3.10).

The Lord wore the makarakundalas in his ears, makaranetunikulaik kātu (MOLI 7.3.10). He was armed with the disc in a hand. His colour was the same as the primeval ocean (MOLI 7.3.11).

The experts in four Vedas were present to perform sacrifices, nānnmaraiyālarum vélviyōva (MOLI 7.3.6). The voice of the Vedas and festivities were resounding endlessly, vêtavoliyum vilâavoliyum (MOLI 7.3.1). The festivities were ongoing every month and every day without fail, tinkkalum nālum vilāovarāta (MOLI 7.3.3). 


\section{Vaikuntam}

Nam has noted the ksetra in two verses (MOLI 9.2.4, 8). Nam says the Lord is reclining at Pulinkuti, seated at Varakunamankai and standing at Vaikuntam. Today the mülabera is standing. The Lord's posture was so enrapturing that the congregating devotees created a scene by presenting a dance recital, nāinkal küttāti niñrārppa (MOLI 9.2.4). The mystic adds the Lord is present at Tiruvaikuntam (Skt. Śrīvaikuṇtham), tiruvaikuntattull lāy tēva (MOLI 9.2.8).

\section{Puḷinkuṭi}

Nam has a patikam MOLI 9.2 and few stray verses on the ksetra. The mystic adds the Lord is pleased to slumber at Kōlūrakam and Pulininuṭi, Kōlūrakattum puḷinkuțiyum nī tuyin mēvi makilntu (MOLI 8.3.5). Today the mülabera is reclining. The place name is Tiruppulinkuṭi (MOLI 9.2.1-3, 5-7). Repeatedly, it is added the Lord is reclining, kitantāy (MOLI 9.2. 3, 5. 7). The mystic adds: For how long a time did you recline? kițantanāl kițantāyettanai kālam kițatti (MOLI 9.2.3). Palm trees and fertile fields surrounded the place, panaicūl, kalivayal (MOLI 9.2.1, 6). Golden forts surrounded the venue, ponmatilcū $\underline{l}$ (MOLI 9.2.2). The Lord's tiara resembles a bunch of paddy crop, katirmuti (MOLI 9.2.6). His consort was seated on a lotus, tāmaraiman்kai "Maid (seated on) Lotus" (MOLI 9.2.3). The Lord was one who churned the ocean, kuraikațal kațaintavan (MOLI 9.2.11). He measured the three worlds, ulakammūnnralantān (MOLI 9.2.11)

\section{Varakuṇamankai}

The venue is practically not described. Nam notes the Lord seated at Varakuṇamańkai (Skt. Varagunamañga? "Maid whose ethos is to grant boon"), varakunaman்kayiliruntu (MOLI 9.2.4, supra Vaikuntam). Today the mülabera is seated (see fig. 11). 


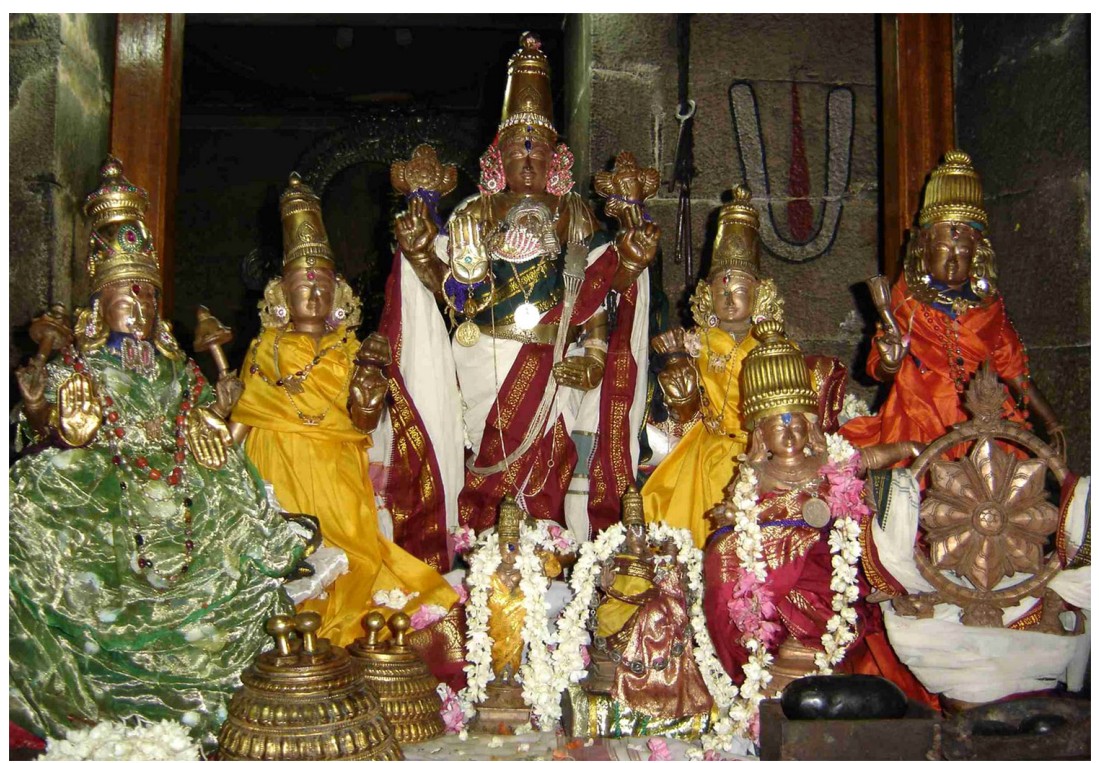

Figure 11: Varakunamañkai, utsavaberas.

\section{Kulantai}

Earlier notified in the Paripattal (supra), very little is told of the venue. Tenkulantai was fitted with a fort in the tower of which a banner was flying, mātakkoți matil (MOLI 8.2.4). The Lord is called Māyakkūttan, one who performs an illusionary dance. He rose high in a war as a dancing bird, Ātalparavai ${ }^{23}$ He was driver of a chariot, bearing the disc. This is likely to be a reference to Pārthasārati. The mülabera is sthänaka (see fig. 12).

${ }^{23}$ This subject has been earlier discussed Kalidos 1999: 229. According to Raju Kalidos, Āṭarparavai "the Dancing Bird" is Garuḍa, one among amiśāvatāras of Viṣnu (Kaidos 1999: Fig. 5). 


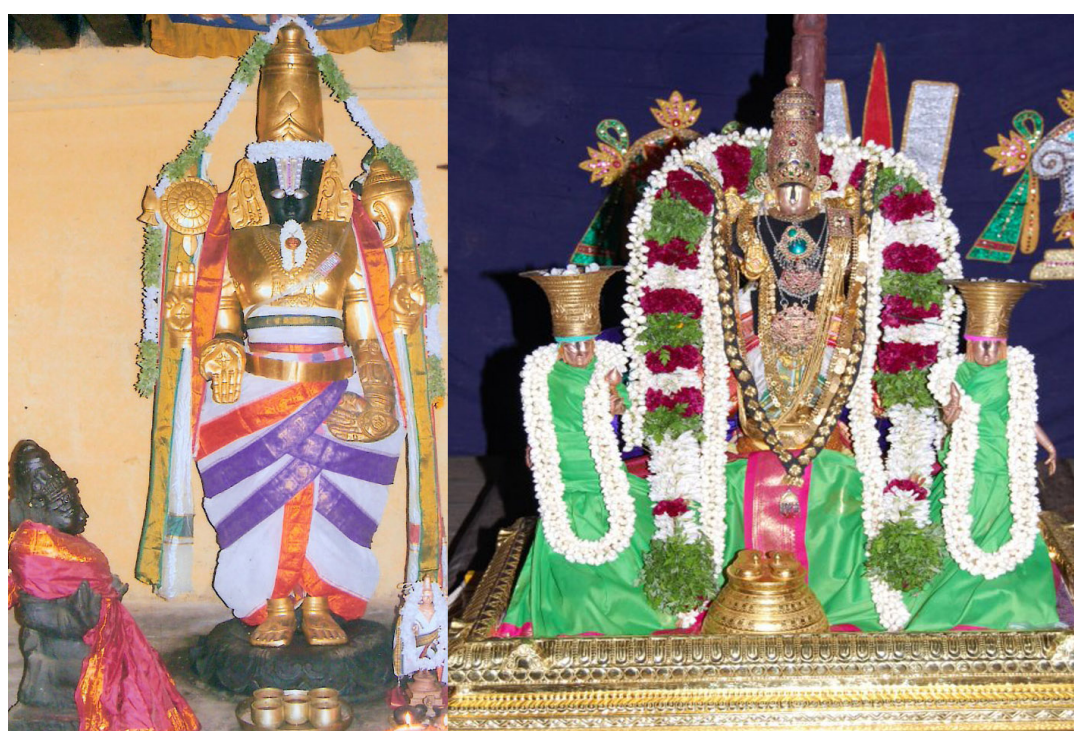

Figure 12: Kulantai, mūlabera and utsavabera.

\section{Kuruñkuṭi}

The ksetra figures in the hymns of Malicai, Nam, Periya and Mańkai. The place name is Kurunkuți (CAN 62; MOLI 1.10.9, 3.9.2; MPT 1.6.8, 5.6.2, 6.3.3, 9.5.1, 3; PTML 11. 228-29; TNT 14), Tirukkurunkuți 5.5.1-2) or Tenkurunkuți (MOLI 1.10.9). The Lord is standing, ninzra (MOLI 1.10.9) or reclining, tuyilum (MPT 9.6.2). Today the mülabera is sthanaka (see fig. 13). The Lord's epithets are Tirumūrti "Sacred Lord" (MOLI 1.10.9), Ātiyañcōti "Primeval Light" (MOLI 1.10.9), Kaṇnan (MOLI 3.9.2), Kuruñkutinampi "Darling of Kurunkuți”" (MOLI 5.5. all hymns), Ponmuți “Golden Crown" (MOLI 5.5.4), Māl-Maṇivaṇnann (MPT 9.5.3), Pēraruḷạlann "Giver of Eternal Bliss" (MPT 9.5.4) and Kōvalar-Kūttan "Dancer-gopa" (MPT 9.5.8). 


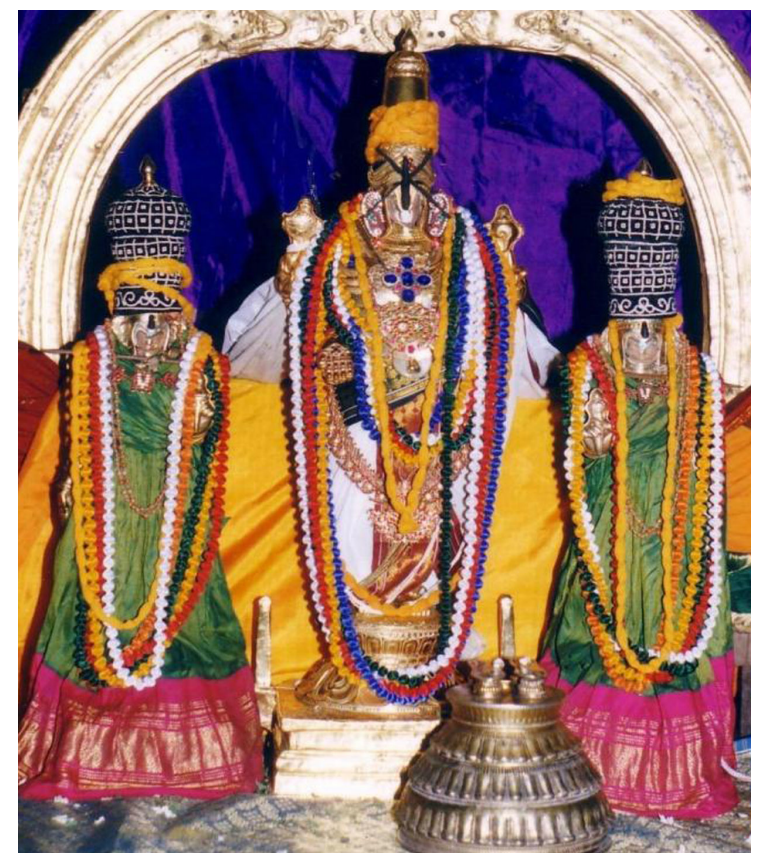

Figure 13: Kuruñkuți, utsavabera.

Something is told of the ecological setting. Fertile fields surrounded the place, kalanicūl (MOLI 3.9.2). It was filled with groves, cōlai (MOLI 5.5.2, 4, 6). Peacocks were practicing dance, mayil payilum (MPT 9.5.3). The sweet smelling mullai flowers were abundant, mullai pulku (MPT 9.5.6). The red-legged stork was in search of food for its partner, ceñkāl ittunai nāraikkiraiteți (MPT 9.6.3). Parrots were training to talk, killai pēcum (MTM 9.6.5)

Few references note the mythological feats of the Lord. He was the Lion who cleft Hiranya into two halves, Iraniyan...irantukūuru ceytukanta cinkam (CAN 62). He devoured the seven seas, seven mountains and the seven worlds, katalèlum malaiyêlivvulakēluntu (MPT 5.6.2). He was the first to stand, having crossed the frontiers of the three worlds, mūvulakun kațantappāl mutalāy ningra (TNT 14).

The Lord's attributes are described. He bears the canku/śankha and $n \bar{e} m i / c a k r a$, and the eyes are lotus-like, tämaraikkan (MOLI 5.5.1, 5, 8). He wears the shining sacred thread, kundalas on ears and bears Śrī on chest, minnnunūlum kunțalamum mārvil tirumaru (MOLI 5.5.2). He wears a golden tiara, ponmuți (MOLI 5.5.4). It was tall, 
nīṇmuṭi (MOLI 5.5.9). His body itself was shining like gold, ponnmēni (MOLI 5.5.7). The hip was slender, cirritai (MOLI 5.5.8). ${ }^{24}$ His face resembled the moon matipōlmukam (MTM 6.3.3).

\section{Kọ̣ūur}

Nammālvār has a patikam on the kṣetra MOLI 6.7. The place name is Tirukkōlūr ( $k \bar{l} l$ is a planet, graha, $\bar{u} r$ residential zone, MOLI 6.7.1-2, $4-5,7) .{ }^{25}$ The Lord is in reclining mode, kitanta (MOLI 6.7.4, 7). Today the mülabea is reclining (see fig. 14).

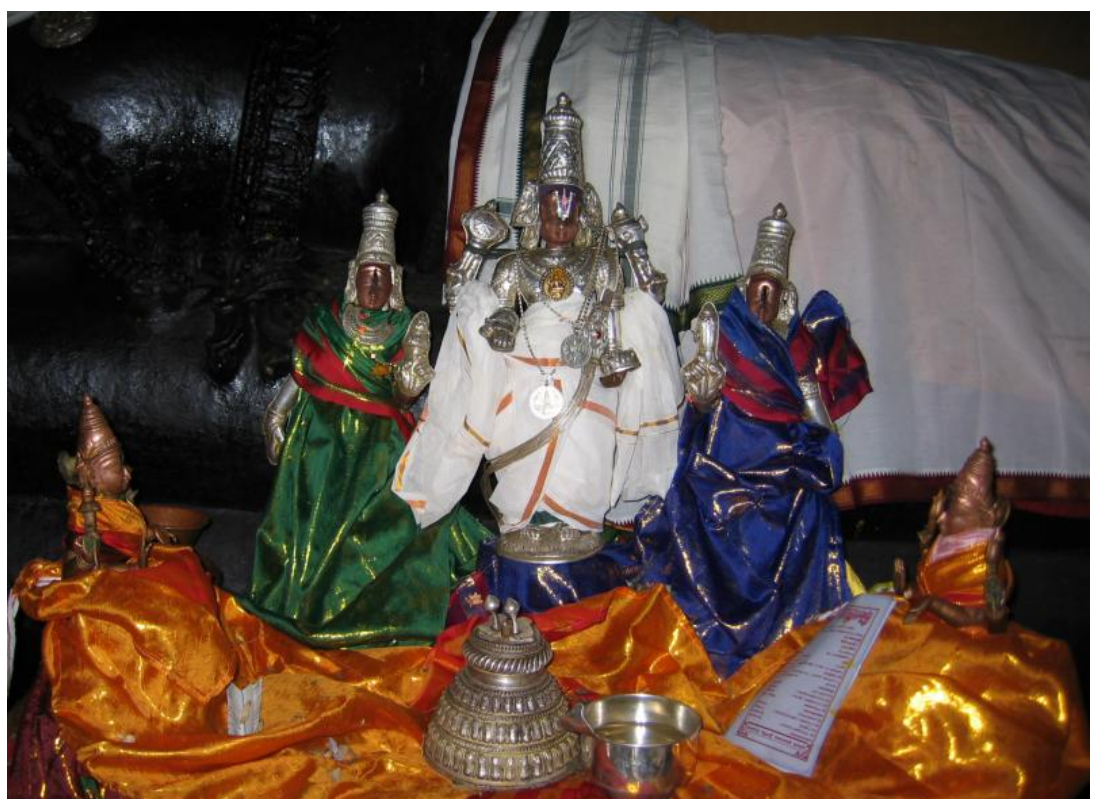

Figure 14: Kōḷūr, mūlabera and utsavabera.

\footnotetext{
${ }^{24}$ This is an attribute of maids usually in Tamil literary tradition.

${ }^{25}$ Those on the banks of the River Tāmiraparani are collectively called Navatiruppati (Nine Sacred Venues) and held in high esteem in the region (Ganeshram 2010 - deals with select six temples). The Navatiruppatis are Kurukūr, Tolaivillimañkalam (called Irattaitiruppati "Twin Temples" that lay on the northern and southern banks of the river), Cīvaramankan, Pēreyil, Vaikuntam, Puḷinkuṭi, Kōḹ̄r, Kuḷntai and Varakunamankai. Each one of the sthala is linked with a köl/graha "planet" among the navagrahas.
} 
The Lord is called Kannan (MOLI 6.7.1) and Matucūtanañ /Madusūdana (MOLI 6.7.11). The Lord's face was soft as the aravinda (a lotus, Nelumbium speciosum or Nyphaea nelumbo) flowers, aravintalōcana (MOLI 6.7.10). With tears in eyes, the devotees throng to the temple (MOLI 6.7.5-6). The Lord is the food that they eat, water that they drink and the betel that they chew, unnum cōru parukunīr tinnum verrilai (MOLI 6.7.1). The parrots on the venue do nothing but to sing the nammāvali of the Lord and get up (early in the Morning), kilikal ...Tirumāl nāmañkaḷe kūviyelum (MOLI 6.7.3).

\section{Argument}

Of all the 18 divyadeśas in the Pāndya country, Māliruñcōlai is the earliest, getting back to the 4th century AD. The data bearing on it is abundant in view of its cult value, increasing though the centuries. At the pan-Indian level, the first Vaiṣnava divyadeśa is Vènkațam that fell within the modest limits of the Tamil country of those times. Its antiquity gets back to the early centuries of the Christian era or even still earlier in the BCEs. The poetic imagination of the mystics would permit them to place Cōlai on a par with Pārkațal and Vēnikațam with Vaikuntha. Kulantai comes next as it is notified in the Paripattal. Meyyam and Tankāl follow suit with earlier rock-cut temples (figs. 4, 5 are rockcut images of the 7 th century $\mathrm{CE}$ ). It is perplexing to note what happened to these deśas during the 5th-7th century. It is a mystery as they reappear only in the hymns of Nammālvar and Mañkai. Tankāl figures in the hymns of Pūtam in the late 5th or early 6th century and may be the rock-cut temple emerged around the end of the 6th century, falling in line with Meyyam. Kōttiiyūr first appears in the hymns of Pūtam. Kurunkuṭi may be dated in the 7th century as it is notified in the hymns of Malicai. Kurukūr, Tolaivillimañkalam, Cīvaramañkai. Pēreyil, Vaikuntam, Pulin̉kuți, Varakuṇamañkai and Kōlūr gained popularity with the versification of Nammālvar in the 8th century. Pullāni may be dated in the late 8th or early 9th century as it appears only in the hymns of Mankai.

An important dimension of the data gleaned from the bhakti hymns is that some of the later names appear in early hymns, e.g. Kālamēkam (Mōkūr), Vāñamāmalai (Cīvaraman̉kai), Alakartannkōyil 
and Meyyamalai (Skt. Satyagiri [Sanskrit satya, Tamil mey]). Scholars proficient in the bhakti hymns must have given these names in later times. Another important dimension is that in most of the places the Lord is associated with dance and called Küttan who performed the pot-dance. The dancing aspect is overwhelmingly linked with Viṣnu in the Pāṇdinādu zone that adds credit to the thesis of Raju Kalidos (1999) whose "Dance of Viṣnu" gets further strengthened. The Lord's performance was so enrapturing that the devotees imitated the same to propitiate the Lord as it was done in early times by the ayar in Cilappatikäram. Since the ayar are said to be founders of the festivities at Māliruñcōlai, in all probability the sojourn of Kaṇnaki in the Cilappatikāram on arriving at Maturai was close to the hill of Alakar where the famous aycciyarkuravai took place.

Why the stance of the Lord should alter in later times while the early tradition was something different? E.g. in Tirumeyyam the original reclining Lord made to sit in later times. The following is the picture of what the Ālvārs have to say on the stance and how they appear today:

\begin{tabular}{|c|c|c|}
\hline Place & $\overline{\text { Ālvār's perception }}$ & As it is Today \\
\hline Māliruñcōlai & $\begin{array}{l}\text { all three (sthānaka, āsana and } \\
\text { sayana) }\end{array}$ & Sthānaka \\
\hline Kōțtiyūr & none of three, simply uraikingra & $\begin{array}{l}\text { aștāingavimāna all three, } \\
\text { balibera: sthānala }\end{array}$ \\
\hline Pullāṇi & nothing told & $\bar{A}$ sana \\
\hline Meyyam & sayana/āsana & Sayana, sthānaka \\
\hline Taṇkāl & nothing told & Sayana, sthānaka \\
\hline Mōkūr & Sayana & sthānaka \\
\hline Kūṭal & nothing told & Așțāngavimāna, all three \\
\hline Villiputtūr & $\bar{a}$ sana or uraikingra & sayana \\
\hline Cīvaramañkai & $\bar{A}$ sana & $\bar{a} s a n a$ \\
\hline Tiruppēreyil & $\bar{A}$ sana & $\bar{a}$ sana \\
\hline Vaikuntham & Sthānaka & sthānaka \\
\hline Pulin̉kuṭi & Sayana & sayana \\
\hline Varakuṇamañkai & Sthānaka & sthānaka \\
\hline
\end{tabular}




\begin{tabular}{|l|l|l|}
\hline Kuḷantai & Kūttan "Dancer"26 & sthānaka \\
\hline Kunuñutịi & Sthānaka, sayana & sthānaka \\
\hline Kōlūur & Sayana & sayana \\
\hline
\end{tabular}

Among these Māliruñcōlai, Meyyam regarding sayana (instead of āsana, sthānaka appears), Villiputtūr (if uraikiñra is sayana), Cīvaramañkai, Tiruppēreyil, Vaikuntam, Pulin̉kuți, Varakuṇamańkai, Kurunkutịi and Kōlūr agree with the original programme of the Ālvārs. Out of eighteen, ten agree with the original visuvalization while in eight the mode differs. This may be due to cult need and the willingness of a donor who wants to see the Lord in a mode suitable to his taste at a time when the temple was rebuilt. Siva-Națarāja in the Cōlanădu circle lifts the left leg while in Pāndyan tradition it is the right. To this effect a myth was inserted as recorded in the Tiruvilaiyātarpurānnam (episode 32) wherein a mythical Pāṇ̣̂a king requests the Lord to alter the usually lifted left leg lest the right may ache. The truth behind may be that the Pāndyas did not want to imitate the Cōla model. Similarly, there should have been some compelling reason to alter the stance of Viṣnu in later times in certain circles. This may apply to other regions such as Cōlanāḍu and Toṇ̣aināḍu.

The Ālvārs were lovers of nature. They had a fascination to highlight environmental and ecological setting of the deśas, the flora and fauna, in unequivocally eloquent terms. No kșetra is exception to this common genre. The delightfully dancing peacocks and pet parrots' mutterings the nāmāvali of Viṣnu are aesthetic poetic vividities. The bees or beetles are ganas and the Cilamapāru flows with honey. The Ālvārs were not only in a frantic-ecstatic search for the beauty-Alakan but also the alakiya "beautiful" setting of his abode in the then temples. All the places were the homes of experts in the $V e d a$ s who nurtured the Vedic sacrifices. Püjās and festivals were busy all the time in addition to offerings, both vegetarian and carnivorous, to the gods as it is told in case of Māliruñcōlai. Ānțậ! calls the brämana lads pārppanaccitțārkal and the folk were bhütas

\footnotetext{
${ }^{26}$ Pioneers in iconographical studies note three modes such as āsana, sthānaka and sayana. Raju Kalidos (1999a: 226, 2006: 17) notes several more from the Tamil Vaișnava hymns. The stances noted are kițantu (recline), iruntu (sit), eluntu (stand), națantu (walk), parantu (fly), kunintu (stoop, contexually dance). This is from the MPT 5.2.4. The MOLI 6.9.3 notes națantu, kitantu and iruntu. The latter account fails to note sthānaka.
} 
that offered the kutippali "blood sacrifices". Therefore, there was no inhibition in either offering the akkäravaticil, a delicious vegetarian dish, or cenkkuruti "(cold) red blood". To be brief, the Ālvārs open new avenues of the divyadeśas and religious mysticism and traditions of their times. Those were the halcyon days as in the later half of the 14th century Gangādevī talks of the foul smell of beef roasted by the vadalistic Muslim at Citamparam, Śrīrangam and Maturai (cf. Kalidos 1997a: 20, Rajarajan 2006: 5).

Before concluding few relevant questions could be raised and answered. How historically/geographically accurate these praises of the sthalas by the Âlvārs might be? This is something like asking what we read in the Psalms and how we view Jerusalem today. There may be some euphemism in what the Ālvārs view each of the sthala, added with poetic imagination. But a sthala should be a reality. The Ālvārs consider those not on earth sthalas, e.g Pārkațal and Paramapatam, due to intuition. They are genuine imaginations. One sould be a Ālvār to undergo such a mystic inspiration. Mortals could not imagine those god-given revelations. All the sthalas came to be attested by epigraphical sources in due course (see Meyyam, Mōkūr and Cittirakūtam in Rajarajan 2006). To be crisp the Âlvars' vision is hazy. We do not find a Meyyam today of what Tirumankai saw in the 9th century. The visual we have presented (photographs and plans; figs 4, 5 are early medieval rockcut images, contemporaneous with the $\bar{A} \underline{\text { lvărs) }}$ are as we find them today. The Ālvārs had no knowledge of the modern visuals. Today's Jerusalem is not what the Psalms view but Jerusalem should have been a reality at the time of the Psalms. Saint David would not believe his own eyes if he were to come alive and say today's Jerusalem is not the pilgrim center that he saw in his time. The same should be the experience of a Ālvār if he visits Mōkūr or Meyyam today. The artistically built tank of the Tirumeyyam temple was in those times a natural water reservoir. Many of the structural additions did not exist in the Meyyam of those times.

We may ask whether the Ālvārs talk of a real temple or idealized vision of a temple that is Viṣnu's home on earth. This carries weight because there could have been no Pārkațal (Ocean of Milk) or Paramapatam (the Vaiṣnava heaven, Vaikuntha). As a devotee of Viṣnu I may have a faith these and believe they exist but as a professor could not establish the reality of these imagined sthalas in a classroom with visual aids. The same yardstick need not be applied to 
historical venues such as Kurukūr and Vaikuntam. Another problem is could the Ālvārs have visited Ayodhyā, Dvārakā and Mathurā in their time. Even if they did not visit, their accounts may be based on what they heard from pilgrims coming from those distant places. It might be "oral history" in a sense. Did not pilgrims visit Rāmeśvaram in the 9th century or did not pilgrims from the south visit Kāśî. If a Śankkarācārya could visit Kāshmīr and Kāśīi, why not Tirumañkai visit Vatariyācciramam (Badrinatha)? Eric Issac 1960 called the sacred venues "the landscape of myth", which may or may not be applicable to all the divyadeśas or tiruttalams. The Ālvārs and Nāyanmār have not told us a fairy tale. They may say $50 \%$ is $100 \%$ but nobody dare say it is $0 \%$.

Another important question is how the sthalas came to be canonized in the Ālvār tradition and Śrivaiṣnava tradition. In fact there is no such two "Ālvār tradition" and "Śrīvaiṣnava tradition". The Ācāryas in their Sanskritic or manipravāla lore commented on what the Ālvārs earlier said. What was told by the Ālvār in two lines might have been interpreted by the Ācāryas in 200 pages. We may even add imagination flies at a bullet-train speed in the Ācārya accounts (e.g. Ānțạl taking the hand of Ranganātha who refers to this sthala in her hymns - Árāyirappați pp. 45-50). But, if there were 108 divyadeśas in Ālvār literature, it was not 1,008 in Ācārya literature. One thing is certain, the Arañkam (Śrīrangam) of the time of Toṇtarațippoṭi as told in his Tirumālai (8th century CE) was not the Arankam of Rāmānujācārya (12th century CE). The Arañkam of Rāmānuja's time is not what we find today. After the Islamic depredations of the 14th century, the temple had undergone drastic changes at the hands of the Vijayanagara-Nāyaka rulers of South India. The same must have been the case with several other sthalas such as Kūtal/Maturai and Cittirakūțam. The Cittirakūtam did not exist during the 12th-17th century due to fanatical activities of a mythical Cōla called Kṛmikanthha as told in the Ācārya guruparamparāprabhāvam. It was rebuilt during the time of Achyutarāya (CE 1529-42) in the 16th century.

We may also consider whether these are the main temples or a sporadic listing of temples. Dr Jeyapriya Rajarajan 2012 has worked on this question and communicated an article to the IAHA, Java. She says during the Early Ālvār Period (6th-7th century) only 16 sthalas are listed. During the Middle Ālvār Period (7th-8th centuries) 42 were 
added, total $16+42=58$. The total 108 reached fruition at about the 9 th century by the time of Tirumankai. It is added that the Śrîtattvanidhi of Kṛṣnarāja Uțaiyar (19th century) of Mysore presents a list of 117 divyadeśas, citing the Brahmānda Purāna (CE 350-950, O'Flaherty 1994: 17). The total 108 seems to have risen to 117 in the 10 th century. Today it might be incredibly more. ${ }^{27}$ So, what the Ālvārs chose to extol were the choicest venues. This as well applies to the cult of Murukan. Prof. Raju Kalidos raised this question in an international conference at Mauritius. The Tamil Tirumurukārrruppatai (c. 3rd century CE) talks arupațaivītu (six houses or sthalas) of the Murukan cult in Tamilnadu. Were they only six? Defintely it was not. What the poet, Nakkīrar, did was to extol the most prominent among the various other sthalas. The same applies to the Ālvārs.

The vital point for consideration is: what kind of history we deal with? What kind of information we get? And how we learn by the larger import? The data I have presented in based on the Ālvār literature. This kind of data is not known to the scholars in the west and North India. While talking of Vaisnavism, they go either to the Bhāgavata Purāna or Gìtagovinda (Bhandarkar 1995). Why not consider the the roots of these two Sanskritic sources that we find in the Tamil Nālāyiram (cf. Hardy 1983, Kalidos 1999a). My emphasis is on the Tamil source that is very much neglected in North India and the west. Few scholars in the United States, e.g. A.K. Ramanujam 1981, who work on Śrīvaiṣnavism do not compliment their presentations with authentic art historical material, which I have done. Prof. George W. Spencer, writing in 1970 on Śaiva "sacred geography", said a similar work on Vaiṣnavism is warranted. To quote: "a study of Vaișnavite sacred geography... is obviously feasible" (Spencer 1970: 233). This is what exactly I have done after 40 years of the dream of a learned Tamil scholar. This in a way is a pioneering study and more work could be done on Cōlanātu, Malaināṭu, Toṇțaināṭu, Vațanāṭu (cf. Jeypriya 2010).

\footnotetext{
${ }^{27}$ For a survey of the temple cars of Tamilnadu, Raju Kalidos (1989: 261-73) listed 64 Viṣnu temples of which 18 were extolled in the hymns of the Ālvārs. That means 45 were not canonized.
} 


\section{Abbreviations}

ANT Nācciyār Tirumoli of Āṇtāạ

CAN Tiruccantaviruttam of Tirumalicai

CTML Ciriyatirumatal of Mankikai

MOLI Tiruvāymoli of Nam

MPT Periya Tirumoli of Mankai

NTV Nānnmukan Tiruvantāti of Tirumalicai

PAL Tiruppallāṇṭu of Periyālvār

PTM Tirumoli of Periyālvār

PTML Periyatirumațal of Mañkai

Skt. Sanskrit

T. Tamil

T I Tiruvantāti I of Poykai

T II Tiruvantāti II of Pēy

TKT Tirukkuruntāṇtakam of Mañkai

TNT Tirunetuntāntakam of Mañkai

Note: The author's have slightly modified the abbreviation scheme of Hardy 1983 and Kalidos 1999.

\section{Acknowledgement}

The author dedicates this small piece of work to Prof. Friedhelm Hardy, thanks to his path-finding study on Tamil Krșna cult. The author is grateful to Prof. Raju Kalidos of the Tamil University of for guidance in interpreting certain enigmatic passages in the Nâlāyiram.

\section{References}

Aiyangar, S. Krishnasvami (1940), A History of Tirupati, 2 vols. Madras.

Ārāyirappați-Guruparamparāprabhāvam, ed. S. Krishnaswamy Ayyangar, Tiruchi n.d.

Bhagavadgītā (1977), Ramakrishna Mutt ed., Tiruparaitturai.

Bhandarkar, R.G. (1913/1995), Vaiṣnavism, Śaivism and Minor Religious Systems. New Delhi. 
Bhaskaran, G. (2001), Jain Philosophy as Expounded in Mērumandara Purāṇam. In Haripriya Rangarajan et al. eds. Jainism: Art, Architecture, Literature \& Philosophy. Delhi.

Brockington, J.L. (1981/1991), The Sacred Thread. Edinburgh.

Ganeshram, S. (2010), Vaiṣnava Divyakșetras in the Southern Pāṇdya Country (Ph.D. thesis, Madurai Kamaraj University). Madurai.

Hanumanthan, K.R. (1996-97), Evolution of Untouchability in Tamilnadu upto AD 1600. In: The Indian Historical Review, XXIII: 1-2, 41-65.

Hardy, Friedhelm (1983), Viraha Bhakti: the Early History of Krș̣na Devotion in South India. Delhi.

Issac, Eric (1960), Religion, Landscape, and Space. In: Landscape, Vol. IX, pp. 14-18.

Jeyapriya Rajarajan (2004), A Note on Vaccirakkōttam. In: East and West, 54: 1-4, 291-302. (2012), Pre-Medieval Phase of Vișnuism in Tamilnadu. Abstract, p. 64. The 22nd Conference of International Association of Historians of Asia (Java).

Kalidos, Raju (1976), History and Culture of the Tamils from Prehistoric times to the President's Rule. Dindigul. (1989), Temple Cars of Medieval Tamilaham. Madurai: Vijay Publications, Madurai. (1996), Natarāja as portrayed in the Tēvāram Hymns. In: Acta Orientalia, 57: 13-56. (1997), The Hymns of Kōtai: An Essay in Eroticism. In R. Kalidos ed. Sectarian Rivalry in Art and Literature, pp. 117-38. Delhi. (1997a), Antiquity of Tillai-Citirakūtam. In: South Asian Studies, Oxford \& IBH, 13, 17-24.

(1999), the Sātavāhanas and the Cankkam Age. In: Ajay Mitra Sastri (ed.), The Age of the Sātavāhanas, pp. 144-55. New Delhi. 
(1999a), Dance of Viṣnu: the Spectacle of Tamil Ālvārs. In: Journal of the Royal Asiatic Society, 3:9:2, 223-50.

(2006), Encyclopaedia of Hindu Iconography: Early Medieval, Vol. I Viṣnu. Delhi: Sharada Publihsing House.

Latha, Velu (2005), Cave Temples of the Pạndya Country... Delhi.

Mani, V.R. (1939/1990), Sons of Sivas: A Study in the Religious Cults of Gaṇeśa and Kārttikeya. Delhi.

Nālāyiram: Nālāyirativviyapirapantam, ed. V.N. Devanathan, Madras 1972 (all the citations on the texts listed under the abbreviations are from this edition).

O'Flaherty, Wendy Doniger (1975/1994), Hindu Myths. Penguin Books, New Delhi.

Pandarathar, K. Sadasiva (1974), Pịkālaccōlar Varalāru (History of the Later Cōlas) in Tamil. Annamalai Nagar.

Ragunath, M. (2005/2008), Nāyaka Temples of Central Tamilnadu (forthcoming). Sharada Publishing House, Delhi.

Rajarajan, R.K.K. (1995), Alakarkoyil Art and Mythology with special reference to the Kalyanamandapa (M. Phil thesis, Madurai Kamaraj University). Madurai.

(2001), Further Light on the Tirupparankunnram Caves. Annali Istituto Orientale, Naples, 51: 4, pp. 295-408.

(2004), Nālirumūrtti-Așțamūrti: the Alakarkōyil Tradition. In P. Chenna Reddy (ed.), Brahma Sri Researches in Archaeology, History \& Culture in the New Millennium (Dr P.V.

Parabrahma Sastry Felicitation Volume), 2 vols, pp. 8691.Sharada Publishing House, Delhi.

(2006), Art of the Vijayanagara-Nāyakas, 2 vols. Sharada Publishing House, Delhi.

Ramanujam, A.K. (1981), Hymns for the Drowning. Princeton.

Sastri, K.A. Nilakanta (1929/72), The Pandyan Kingdom. Madras.

Spencer, George W. (1970), Sacred Geography of the Tamil Shaivite Hymns. In: Numen, Vol. 17:3, pp. 232-44. 
Tēvāram (1972), 2 vols. Kalakam ed. Madras.

Tiruvilaiyātararpurānam of Perumparrappuliyūr Nampi, Chennai 1906/1972.

Zvelebil, Kamil V. (1974) Tamil Literature under History of Indian Literature ed. Jan Gonda. Stuttgart. 
